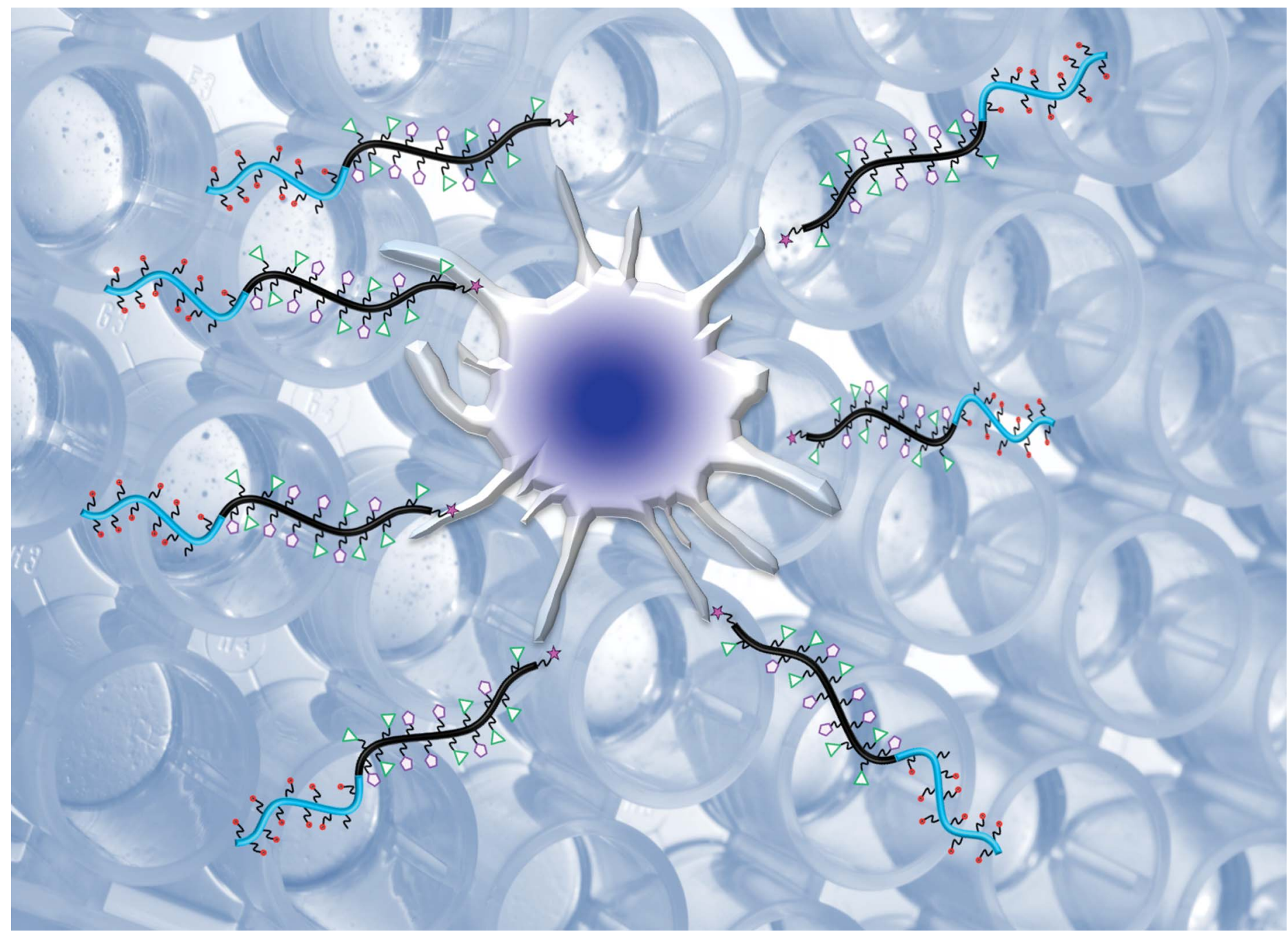

Showcasing the joint research from the laboratories of Volga Bulmus at the Izmir Institute of Technology and Remzi Becer at the Queen Mary University of London.

Title: A new proton sponge polymer synthesized by RAFT polymerization for intracellular delivery of biotherapeutics

Novel block copolymers have been developed with a sperminelike block and a mannose block. These block copolymers are potential endosomal escaping agents, and their cytotoxicity and polyplex formation have been demonstrated in this joint project, funded by the British Council UK-Turkey Knowledge Partnership Programme.

\section{As featured in:}

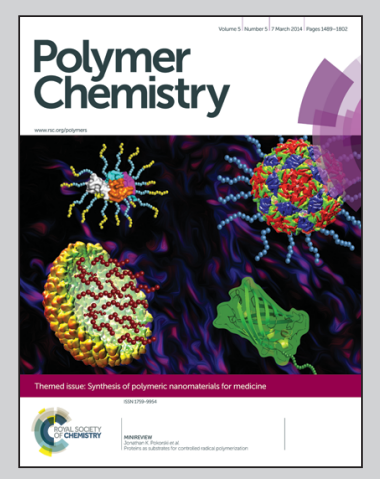

See I. Kurtulus et al., Polym. Chem., 2014, 5, 1593. 
Cite this: Polym. Chem., 2014, 5, 1593

\title{
A new proton sponge polymer synthesized by RAFT polymerization for intracellular delivery of biotherapeutics $\uparrow$
}

\author{
Isil Kurtulus, ${ }^{a}$ Gokhan Yilmaz, ${ }^{\mathrm{b}}$ Muhammed Ucuncu, ${ }^{\mathrm{c}}$ Mustafa Emrullahoglu, ${ }^{\mathrm{c}}$ \\ C. Remzi Becer*bd and Volga Bulmus*ae
}

A spermine-like polymer was synthesized via reversible addition-fragmentation chain transfer polymerization as a potential endosomal escaping agent. A new methacrylate monomer, 2-((tertbutoxycarbonyl)(2-((tert-butoxycarbonyl)amino)ethyl)amino)ethylmethacrylate (BocAEAEMA), was prepared and then polymerized via RAFT polymerization at constant monomer or initiator concentration at varying $[M] /[R] /[l]$ ratios. In all polymerizations, $\ln [M]_{0} /[M]$ increased linearly with time. The linear increase in $M_{n}$ with monomer conversion was also observed. $\mathrm{P}$ (BocAEAEMA)s with controlled molecular weights and narrow molecular weight distributions were obtained. The in vitro cytotoxicity and proton sponge capacity of deprotected polymers P(AEAEMA) were investigated in comparison with a widely used endosomal-disruptive polymer, PEI. P(AEAEMA)s were found to possess proton sponge capacity comparable with PEI. More importantly, P(AEAEMA)s were not toxic on NIH 3 T3 cells at concentrations where PEI (25 kDa) was highly toxic $(0.4 \mu \mathrm{M}$ and above). P(AEAEMA) was able to fully condense a DNA fragment at nitrogen/phosphate (N/P) ratios of 10 and above, as evidenced by gel electrophoresis. $P(B o c A E A E M A)$ was then chain-extended with a model sugar monomer, mannose-acrylate (ManAc), to yield $P(A E A E M A)-b-P(M a n A c)$ block copolymers, to potentially provide cell-recognition ability to the polyplex particles. Although the presence of the $\mathrm{P}(\mathrm{ManAc})$ block partially inhibited the interaction of $P(A E A E M A)$ with DNA, $P(A E A E M A)_{13}-b-P(M a n A c)_{7}$ was able to form polyplexes with DNA at N/P ratios ranging between 20/1 and 2/1. Dynamic light scattering measurements showed that while P(AEAEMA) $\left(M_{\mathrm{n}}=5.5 \mathrm{kDa}\right)$ and DNA formed polyplex particles having a hydrodynamic diameter $\left(D_{\mathrm{h}}\right)$ of $125 \pm 51 \mathrm{~nm}$, $\mathrm{P}(\mathrm{AEAEMA})_{13}-b-\mathrm{P}(\mathrm{ManAc})_{7}$ and DNA formed particles with a smaller $D_{\mathrm{h}}$ of $38 \pm 10 \mathrm{~nm}$.

Received 6th September 2013 Accepted 6th November 2013

DOI: $10.1039 /$ c3py01244a

www.rsc.org/polymers

\section{Introduction}

Challenges in intracellular delivery of macromolecular biotherapeutics ( $25 \mathrm{kDa}$ ) limit the applications of several treatment strategies such as gene therapies. ${ }^{1-4}$ Macromolecular therapeutics such as DNA and siRNA are usually taken up by cells through the endocytosis mechanism in which the therapeutics

\footnotetext{
${ }^{a}$ Department of Chemical Engineering, Izmir Institute of Technology, Gulbahce, Urla, Izmir, 35430, Turkey.E-mail:volgabulmus@iyte.edu.tr

${ }^{b}$ Department of Chemistry, University of Warwick, CV4 7AL, Coventry, UK. E-mail: r.becer@qmul.ac.uk

${ }^{c}$ Department of Chemistry, Izmir Institute of Technology, Gulbahce, Urla, Izmir, 35430, Turkey

${ }^{d}$ School of Engineering and Materials Science, Queen Mary University of London, Mile End Road, E1 4NS, London, UK

${ }^{e}$ Biotechnology and Bioengineering Graduate Programme, Izmir Institute of Technology, Gulbahce, Urla, Izmir, 35430, Turkey

$\dagger$ Electronic supplementary information (ESI) available: ManAC synthesis procedure, ${ }^{1} \mathrm{H}$-NMR spectra of compounds and polymers, calculations of yields, monomer conversions, molecular weights and GPC chromatograms. See DOI: 10.1039/c3py01244a
}

are entrapped inside acidic membrane vesicles called endosomes and then transferred to lysosomes where they get degraded. There are certain agents displaying the ability to transport macromolecular therapeutics from endosomes. These include certain cationic molecules and poly(cations) such as spermine/spermidine and poly(ethyleneimine) (PEI). Spermine and spermidine are natural amines that have been used as endosomal escaping agents in intracellular drug delivery. ${ }^{5-12}$ Systems containing these natural amines have shown high biocompatibility, nucleic acid binding activity and transfection activity. PEI is a synthetic poly(amine) that has also been widely used in intracellular delivery of genes and nucleic acids. ${ }^{\mathbf{1 3 - 1 6}}$ While PEI displays high transfection ability, high dose-dependent toxicity constitutes its major drawback. ${ }^{16,17}$ Importantly, both spermine, spermidine and PEI structures contain primary and secondary amine groups which cause the proton-sponge effect in the acidic environment of endosomes, leading to endosomal rupturing. .,18,19 $^{\text {, }}$

The reversible addition-fragmentation chain transfer (RAFT) polymerization technique has been used for preparation of a number of well-defined polymers having only primary and/or 
tertiary amine groups. ${ }^{20-31}$ Some of these polymers could be used efficiently to complex nucleic acid therapeutics and displayed to a certain degree endosome escaping ability possibly through the proton-sponge effect. ${ }^{27,29-31}$ A few polymers with proton-sponge capacity were also derived from functional polymer precursors such as oxazoline and pentafluorophenyl ester polymers synthesized via RAFT polymerization..$^{22,32,33}$

In this study, we intended to synthesize a new, spermine/ spermidine-like polymer via RAFT polymerization as a potential endosomal escaping agent. The ability of the RAFT technique to yield polymers with controlled molecular weight, narrow molecular weight distribution, controlled structure and endgroup functionality makes this technique an excellent synthetic tool to prepare polymer therapeutics..$^{34-40}$ Firstly, a new methacrylate monomer, namely 2-((tert-butoxycarbonyl)(2-((tertbutoxycarbonyl)amino)ethyl)amino)ethylmethacrylate (BocAEAEMA), was prepared and then polymerized via RAFT polymerization. A series of RAFT polymerization kinetics experiments were performed in order to investigate the RAFT-controlled character of polymerizations. Following the deprotection of the amine groups to yield P(AEAEMA), the in vitro cytotoxicity on NIH 3T3 cells and the proton sponge capacity of polymers in comparison with PEI were investigated. Furthermore, the $\mathrm{P}$ (BocAEAEMA) macro-RAFT agent was chain extended with a mannose-acrylate monomer (ManAc), and then deprotected to yield P(AEAEMA)- $b$-P(ManAc). The nucleic acid complexation ability of the copolymer and the particle size of the nanoplexes formed have been investigated. The results of these experiments are presented below.

\section{Experimental}

\section{Materials}

$N$-Hydroxyethylethylenediamine (99\% purity) and di-tert-butyl dicarbonate were purchased from Aldrich to use in the synthesis of tert-butyl(2-((tert-butoxycarbonyl)amino)ethyl)(2hydroxyethyl)carbamate according to the procedure reported by Moura et al. ${ }^{\mathbf{4 1}}$ Methacryloyl chloride was purchased from Aldrich. tert-Butyl(2-((tert-butoxycarbonyl)amino)ethyl)(2hydroxyethyl)carbamate was methacrylated according to the procedure reported previously. ${ }^{42,43}$ A chain transfer agent, 4cyano-4-(phenylcarbonothioylthio) pentanoic acid (CPADB), was purchased from Aldrich. 2,2'-Azobis(2-methylpropionitrile) (AIBN) was used after recrystallization twice in methanol. Silica gel (pore size $60 \AA$, 70-230 mesh) was purchased from Fluka. Acetic acid, sodium acetate, citric acid and mono- and dibasic phosphate salts were used to prepare buffer solutions and purchased from Merck. Polyethyleneimine (branched, $M_{\mathrm{n}}$ : $25 \mathrm{kDa}$ and $60 \mathrm{kDa}$; and linear, $M_{\mathrm{n}}: 8 \mathrm{kDa}$ ) was purchased from Sigma-Aldrich and Fluka.

Toluene, ethylacetate, hexane, dichloromethane (DCM), trifluoroacetic acid, deuterium oxide $\left(\mathrm{D}_{2} \mathrm{O}\right)$, deuterium chloroform $\left(\mathrm{CDCl}_{3}\right)$, triethylamine (TEA), hexylamine, diethyl ether, methanol and $N^{\prime}, N^{\prime}$-dimethylacetamide (DMAc, HPCL grade $\geq 99.9 \%$ ) were purchased from Sigma. The dialysis membrane $(\mathrm{MWCO}=500-1000 \mathrm{Da})$ was purchased from Spectrum ${ }^{\circledR}$ Laboratories.
DMEM (Dulbecco's Modified Eagle's Medium), L-glutamine, trypsin and FBS (Foetal Bovine Serum) were obtained from Gibco. PBS (phosphate buffer saline solution, $\mathrm{pH}$ 7.1) was prepared using relevant mono- and dibasic salts and $\mathrm{NaCl}$. The thiazolyl Blue Tetrazolium Blue (MTT) reagent was bought from Sigma-Aldrich. The epithelial mouse fibroblast (NIH 3T3) cell line was kindly provided by Bioengineering Research and Application Centre (İzmir Institute of Technology, Turkey).

The mannose acrylate (ManAc) monomer was synthesized according to a procedure reported in the literature (Fig. S1-13, ESI $\dagger$ ). ${ }^{44}$ Ethidium bromide (Sigma), agarose (Sigma), $1 \times$ TAE buffer and 100 bp-marker (Fermentas, gene ruler) were kindly provided by Bioengineering Research and Application Centre (Izmir Institute of Technology, Turkey). The 700-bp DNA fragment was kindly provided by Dr G. Mese-Ozcivici (Department of Molecular Biology and Genetics, İzmir Institute of Technology, Turkey).

\section{Instrumental methods}

Nuclear magnetic resonance spectroscopy. ${ }^{1} \mathrm{H}$ NMR spectroscopy (Varian, VNMRJ 400 spectrometer) was used to determine the chemical structure of compounds synthesized and the conversion of the monomers during polymerizations. Samples were dissolved at $10 \mathrm{mg} \mathrm{ml}{ }^{-1}$ concentration in $\mathrm{D}_{2} \mathrm{O}$ or $\mathrm{CDCl}_{3}$ depending on the solubility of the samples.

Gel permeation chromatography. Gel permeation chromatography was used to determine the molecular weight and molecular weight distribution of polymers. A Shimadzu modular system comprising an SIL-10AD auto-injector, PSS Gram $30 \AA$ and $100 \AA(10 \mu \mathrm{M}, 8 \times 300 \mathrm{~mm})$ columns, an RID-10A refractive-index detector and an SPD-20A prominence UV-vis detector calibrated with narrow polydisperse poly(methyl methacrylate) standards (410-67000 $\mathrm{g} \mathrm{mol}^{-1}$ ) was used for analysing $\mathrm{P}$ (BocAEAEMA). The mobile phase was $N^{\prime}, N^{\prime}$-dimethylacetamide containing $0.05 \% \mathrm{w} / \mathrm{v} \mathrm{LiBr}$. GPC measurements of $\mathrm{P}$ (AEAEMA)- $b$-P(ManAc) (performed at University of Warwick) was conducted on a Varian 390-LC system in DMF $\left(1 \mathrm{~g} \mathrm{~L}^{-1} \mathrm{LiBr}\right)$ at $50{ }^{\circ} \mathrm{C}$, equipped with refractive index, viscometry and UV absorption detectors, $2 \times$ PLgel $5 \mathrm{~mm}$ mixed-D columns $(300 \times$ $7.5 \mathrm{~mm}), 1 \times$ PLgel $5 \mathrm{~mm}$ guard column $(50 \times 7.5 \mathrm{~mm})$ and autosampler. Narrow linear poly(methyl methacrylate) standards in the range of 200 to $1.0 \times 10^{6} \mathrm{~g} \mathrm{~mol}^{-1}$ were used for calibration.

UV-visible spectrophotometry. UV-visible spectrophotometry was used to investigate the aminolysis of the RAFT end-group of BocAEAEMA polymers. The UV-visible absorbance of the RAFT end-group was measured using a Thermo Scientific Evolution 201 UV-visible spectrophotometer in the range between $200 \mathrm{~nm}$ and $600 \mathrm{~nm}$ using quartz cuvettes. Briefly, the polymer was dissolved in methanol at a concentration of $0.004 \mathrm{M}$. Hexylamine $(0.04 \mathrm{M})$ and triethylamine $(0.04 \mathrm{M})$ were then added to polymer solution. The aliquot of $10 \mu \mathrm{l}$ was diluted to $600 \mu \mathrm{l}$ with methanol before the measurement was taken. The absorbance of the diluted solution was scanned at $0,5 \mathrm{~h}$ and $7 \mathrm{~h}$ of reaction.

Microplate reader. In cytotoxicity analysis, a Thermo Electron Corporation Varioskan microplate reader was used to 
measure the absorbance of cell solutions in a 96-well plate at $540 \mathrm{~nm}$.

Agarose gel electrophoresis. The electrostatic complexation of DNA with polymers was investigated by agarose gel electrophoresis using a Thermo Scientific Owl ${ }^{\mathrm{TM}}$ EasyCast $^{\mathrm{TM}}$ B1 mini gel system.

Dynamic light scattering. Particle size measurements of polyplexes of DNA with polymers were performed using a Malvern NanoZS Particle Analyzer System.

\section{Synthetic methods}

Synthesis of 2-((tert-butoxycarbonyl)(2-((tert-butoxycarbonyl)amino)ethyl)amino)ethyl methacrylate (BocAEAEMA) (2). The amine containing monomer was synthesized according to the procedure shown in scheme 1 . The primary and secondary amine groups of $\mathrm{N}$-(2-hydroxyethyl)ethylenediamine were first protected using di-tert-butyl dicarbonate according to the procedure reported by Moura et al. ${ }^{41}$ Briefly, $N$-(2-hydroxyethyl)ethylenediamine $(0.024 \mathrm{~mol}, 2.43 \mathrm{ml})$ was dissolved in dry DCM $(40 \mathrm{ml})$ at $-10^{\circ} \mathrm{C}$. Di-tert-butyl dicarbonate $(0.048 \mathrm{~mol})$ was dissolved in dry DCM $(40 \mathrm{ml})$. Di-tert-butyl dicarbonate solution was added dropwise into $N$-(2-hydroxyethyl)ethylenediamine solution at $-10{ }^{\circ} \mathrm{C}$. The final solution was purged with nitrogen for about $3 \mathrm{~h}$ and stirred for $24 \mathrm{~h}$ at room temperature under nitrogen atmosphere. After reaction, the precipitate formed during the reaction was separated by filtration. In order to remove the unreacted $N$-hydroxyethylethylenediamine, water-DCM extraction was performed three times. The organic phases were collected and the solvent was removed using a rotary evaporator. The product, tert-butyl2-(((tert-butoxycarbonyl)amino)ethyl)(2-hydroxyethyl)carbamate (BocAEAE) (1) was collected as a yellow oil (reaction yield: 64\%; total yield: $64 \%)$.

${ }^{1} \mathrm{H}$ NMR $\left(\mathrm{CDCl}_{3}, \delta\right.$ in ppm): 5.14-4.97 (s, $1 \mathrm{H},-\mathrm{CH}_{2}-\mathrm{NH}-$ $\left.\left(\mathrm{COO}\left(\mathrm{CH}_{3}\right)_{3}\right)\right), 3.71\left(\mathrm{t}, 2 \mathrm{H},-\mathrm{CH}_{2}-\mathrm{CH}_{2}-\mathrm{OH}\right), 3.33-3.20(\mathrm{t}, 6 \mathrm{H}, \mathrm{OH}-$ $\mathrm{CH}_{2}-\mathrm{CH}_{2}-\mathrm{N}\left(\mathrm{COO}\left(\mathrm{CH}_{3}\right)_{3}-\mathrm{CH}_{2}-\mathrm{CH}_{2}-\mathrm{NH}\left(\mathrm{COO}\left(\mathrm{CH}_{3}\right)_{3}\right)\right.$, 1.49-1.39 (s, $\left.18 \mathrm{H}-\mathrm{N}\left(\mathrm{COO}-\left(\mathrm{CH}_{3}\right)_{3}\right)\right)-\mathrm{CH}_{2}-\mathrm{CH}_{2}-\mathrm{NH}-\left(\mathrm{COO}\left(\mathrm{CH}_{3}\right)_{3}\right)$.

BocAEAE (1) (0.0154 mol) was dissolved in dry DCM $(40 \mathrm{ml})$ at $0{ }^{\circ} \mathrm{C}$. Triethylamine $(0.043 \mathrm{~mol})$ was dropped into the solution under $\mathrm{N}_{2}$. The solution was stirred for $30 \mathrm{~min}$. Finally, methacryloyl chloride $(0.029 \mathrm{~mol})$ was added dropwise into the solution. The final solution was stirred for $4 \mathrm{~h}$ at $0{ }^{\circ} \mathrm{C}$ under $\mathrm{N}_{2}$ and for a further $15 \mathrm{~h}$ at room temperature. After reaction, the solution was filtered to remove the salt formed during reaction. The reaction solution was extracted first with brine solution (three times) and then with water (three times). The organic

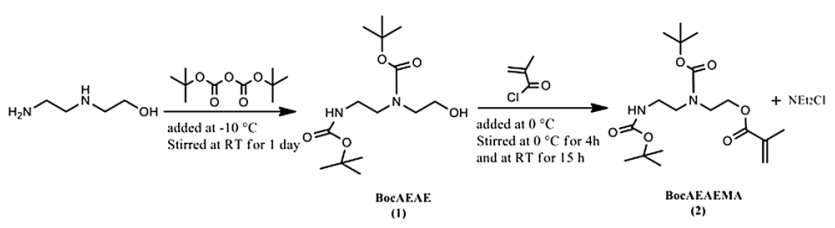

Scheme 1 Synthesis of the amine containing monomer, 2-((tertbutoxycarbonyl)(2-((tert-butoxycarbonyl)amino)ethyl)amino)ethyl methacrylate (BocAEAEMA). phases were collected and the solvent was evaporated using a rotary evaporator. The product was further dried in a vacuum oven. The product was then purified by silica gel column chromatography using hexane (Hxn) and ethylacetate (EA) at varying volume ratios (Hxn : $\mathrm{EA}=1: 0 ; 10: 1 ; 8: 1 ; 6: 1 ; 4: 1$; $2: 1 ; 0: 1)$. The final product, 2 -((tert-butoxycarbonyl)(2-((tertbutoxycarbonyl)amino)ethyl)amino)ethylmethacrylate (BocAEAEMA) (2), was obtained as a yellow oil $\left(R_{\mathrm{f}}=0.19\right.$ in Hxn : EA $=$ 4 : 1 ; total yield: $84 \%$ ).

${ }^{1} \mathrm{H}$ NMR $\left(\mathrm{CDCl}_{3}, \delta\right.$ in ppm): 6.11-5.58 (s, 2H, $\mathrm{CH}_{2}=\mathrm{C}\left(\mathrm{CH}_{3}\right)$ $\mathrm{COO}-), 1.94\left(\mathrm{~s}, 3 \mathrm{H}, \mathrm{CH}_{2}=\mathrm{C}-\mathrm{CH}_{3}\right), 4.25-4.23\left(\mathrm{t}, 2 \mathrm{H},-\mathrm{COO}-\mathrm{CH}_{2}-\right)$, $3.50-3.27 \quad\left(\mathrm{t}, \quad 6 \mathrm{H}, \quad-\mathrm{CH}_{2}-\mathrm{N}\left(\mathrm{COO}\left(\mathrm{CH}_{3}\right)_{3}-\mathrm{CH}_{2}-\mathrm{CH}_{2}-\right.\right.$ $\left.\left.\mathrm{NH}\left(\mathrm{COO}\left(\mathrm{CH}_{3}\right)_{3}\right)\right)\right)$, 1.45-1.42 (s, $18 \mathrm{H}, \quad-\mathrm{N}\left(\mathrm{COO}-\left(\mathrm{CH}_{3}\right)_{3}\right)-\mathrm{CH}_{2}-$ $\mathrm{CH}_{2}-\mathrm{NH}-\left(\mathrm{COO}\left(\mathrm{CH}_{3}\right)_{3}\right), 4.99-4.79\left(\mathrm{~s}, 1 \mathrm{H},-\mathrm{CH}_{2}-\mathrm{NH}-\left(\mathrm{COO}\left(\mathrm{CH}_{3}\right)_{3}\right)\right.$.

RAFT polymerization of 2-((tert-butoxycarbonyl)(2-((tert-butoxycarbonyl)amino)ethyl)amino)ethyl methacrylate (BocAEAEMA). The polymerization scheme and conditions are given in Scheme 2 and Table S1 (ESI $\dagger$ ), respectively. Briefly, in a representative polymerization procedure (Exp. 3, Table S1, ESI $\dagger$ ) BocAEAEMA (2) $\left(5.37 \times 10^{-4} \mathrm{~mol}\right), \mathrm{CPADB}\left(1.07 \times 10^{-5} \mathrm{~mol}\right)$ and $\mathrm{AIBN}(2.69 \times$ $\left.10^{-6} \mathrm{~mol}\right)$ were dissolved in toluene $(540 \mu \mathrm{l})$. The total volume of the reaction mixture was $750 \mu$ l. The solution was purged with $\mathrm{N}_{2}$ for $15 \mathrm{~min}$. The reaction solution was then immersed in an oil bath at $65{ }^{\circ} \mathrm{C}$. At the end of the reaction time, polymerization was stopped by cooling the solution in an ice bath and exposing the solution to air. The solvent was removed under vacuum. Monomer conversions were determined via ${ }^{1} \mathrm{H}-\mathrm{NMR}$ spectroscopy using $\mathrm{CDCl}_{3}$ as a solvent. Polymers (P(BocAEAEMA)) (3) were purified by precipitating the polymerization mixture in hexane (approximately 9 times). The number average molecular weight $\left(M_{\mathrm{n}}\right)$ and molecular weight distribution (PDI) were determined by GPC using DMAc as a mobile phase. Molecular weights were also calculated
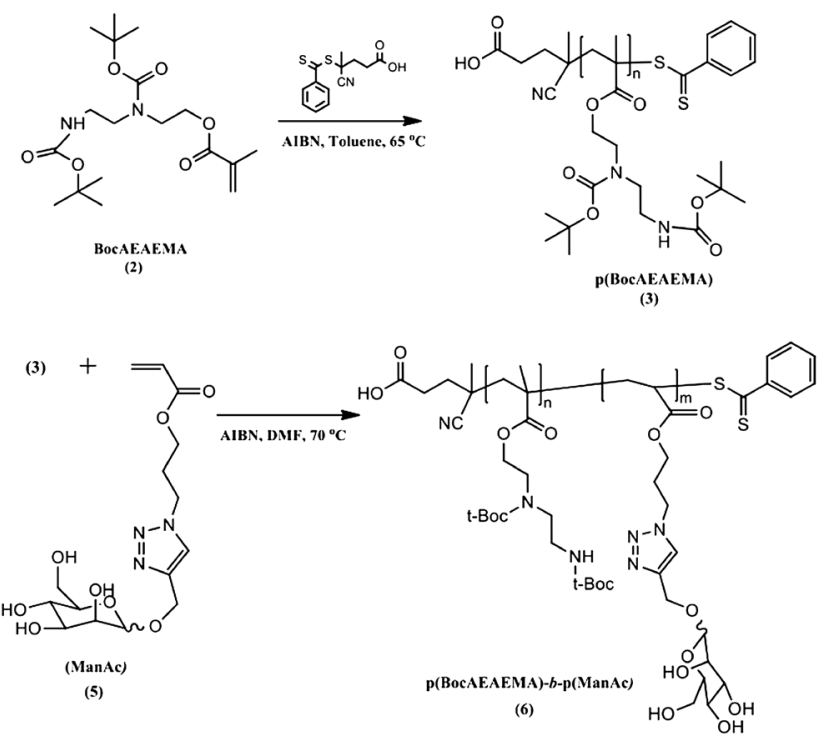

Scheme 2 Synthesis of poly(2-((tert-butoxycarbonyl)(2-((tertbutoxycarbonyl)amino)ethyl)amino)ethylmethacrylate) (P(BocAEAEMA)) (3) and copolymerization of the P(BocAEAEMA) macro-RAFT agent with ManAc to yield $P(B o c A E A E M A)-b-P(M a n A c)$ block copolymers. 
from the ${ }^{1} \mathrm{H}-\mathrm{NMR}$ spectrum of purified polymers using eqn (1) in which the molecular weight of the monomer and RAFT agent is $372.5 \mathrm{~g} \mathrm{~mol}^{-1}$ and $279.4 \mathrm{~g} \mathrm{~mol}^{-1}$, respectively.

${ }^{1} \mathrm{H}$ NMR ( $\mathrm{CDCl}_{3}, \delta$ in ppm): $1.76\left(\mathrm{~s}, 2 \mathrm{H},-\mathrm{CH}_{2}-\mathrm{C}\left(\mathrm{CH}_{3}\right) \mathrm{COO}-\right)$, 0.89-0.73 (s, 3H, $\left.-\mathrm{CH}_{2}-\mathrm{C}\left(\mathrm{CH}_{3}\right) \mathrm{COO}-\right), 4.01$ (t, $\left.2 \mathrm{H},-\mathrm{COO}-\mathrm{CH}_{2}-\right)$, $3.50-3.27\left(\mathrm{t}, 6 \mathrm{H},-\mathrm{CH}_{2}-\mathrm{N}\left(\mathrm{COO}\left(\mathrm{CH}_{3}\right)_{3}-\mathrm{CH}_{2}-\mathrm{CH}_{2}-\mathrm{NH}\left(\mathrm{COO}\left(\mathrm{CH}_{3}\right)_{3}\right)\right)\right.$, 1.45-1.42 (s, $18 \mathrm{H},-\mathrm{N}\left(\mathrm{COO}-\left(\mathrm{CH}_{3}\right)_{3}\right)-\mathrm{CH}_{2}-\mathrm{CH}_{2}-\mathrm{NH}-\left(\mathrm{COO}\left(\mathrm{CH}_{3}\right)_{3}\right)$, 4.98-4.77 (s, $1 \mathrm{H},-\mathrm{CH}_{2}-\mathrm{NH}-\left(\mathrm{COO}\left(\mathrm{CH}_{3}\right)_{3}\right)$.

$$
\begin{aligned}
M_{\mathrm{n}_{\mathrm{NMR}}}= & \frac{\frac{I @ 4.01 \mathrm{ppm}}{2}}{\frac{I @ 7.73 \mathrm{ppm}+I @ 7.52 \mathrm{ppm}+I @ 7.35 \mathrm{ppm}}{5}} \\
& \times M_{\mathrm{w}_{\text {monomer }}}+M_{\mathrm{W}_{\mathrm{RAFT}}}
\end{aligned}
$$

Deprotection of P(BocAEAEMA). Three polymers having different molecular weights $M_{\mathrm{n}}=11500 \mathrm{Da}$, PDI $=1.35$ (GPC), $M_{\mathrm{n}}=12000 \mathrm{Da}(\mathrm{NMR}), \mathrm{DP}=32(\mathrm{NMR}) ; M_{\mathrm{n}}=13500 \mathrm{Da}, \mathrm{PDI}=$ 1.41 (GPC), $M_{\mathrm{n}}=16500 \mathrm{Da}(\mathrm{NMR}), \mathrm{DP}=44$ (NMR); $M_{\mathrm{n}}=23500$ $\mathrm{Da}, \mathrm{PDI}=1.40$ (GPC), $M_{\mathrm{n}}=20400 \mathrm{Da}(\mathrm{NMR}), \mathrm{DP}=55$ (NMR) were deprotected in order to investigate their proton-sponge capacity and in vitro cytotoxicity.

For deprotection of amino groups (removal of Boc groups) (Scheme 3), polymer (3) (4.35 $\mu \mathrm{mol}, 52.2 \mathrm{mg}$ for $M_{\mathrm{n}}=12000$ $\mathrm{Da}$; 71,8 $\mathrm{mg}$ for $M_{\mathrm{n}}=16500 \mathrm{Da} ; 88.7 \mathrm{mg}$ for $\left.M_{\mathrm{n}}=20400 \mathrm{Da}\right)$ was dissolved in DCM $(1 \mathrm{ml})$ and trifluoroacetic acid $(0.5 \mathrm{ml})$ was added dropwise into the solution at $0{ }^{\circ} \mathrm{C}$. The final solution was stirred for $30 \mathrm{~min}$ at room temperature. The solvent was removed by purging $\mathrm{N}_{2}$ at room temperature. The reaction mixture was then washed with diethyl ether and chloroform more than three times and finally the sample was dried in a vacuum oven. The deprotected polymer, poly(2-(aminoethyl)-amino)ethylmethacrylate, P(AEAEMA) (4), was characterized by ${ }^{1} \mathrm{H}-\mathrm{NMR}$ spectroscopy after dissolving in $\mathrm{D}_{2} \mathrm{O}$.

${ }^{1} \mathrm{H}$ NMR $\left(\mathrm{D}_{2} \mathrm{O}, \delta\right.$ in ppm): $4.15\left(\mathrm{t}, 2 \mathrm{H},-\mathrm{COO}-\mathrm{CH}_{2}-\right), 3.41-3.3$ $\left(\mathrm{t}, 6 \mathrm{H},-\mathrm{CH}_{2}-\mathrm{NH}-\mathrm{CH}_{2}-\mathrm{CH}_{2}-\mathrm{NH}_{2}\right), 1.76\left(\mathrm{~s}, 2 \mathrm{H},-\mathrm{CH}_{2}-\mathrm{C}\left(\mathrm{CH}_{3}\right)\right.$ COO-), 0.89-0.73 (s, 3H, - $\mathrm{CH}_{2}-\mathrm{C}\left(\mathrm{CH}_{3}\right) \mathrm{COO}-$ ).

The deprotection yield was calculated using eqn (2).

$$
\text { Deprotection yield } \%=\frac{\frac{\boldsymbol{I} @ 4.15 \mathrm{ppm}}{2}}{\frac{\boldsymbol{I} @ 1.48 \mathrm{ppm}}{18}+\frac{\boldsymbol{I} @ 4.15 \mathrm{ppm}}{2}} \times 100
$$

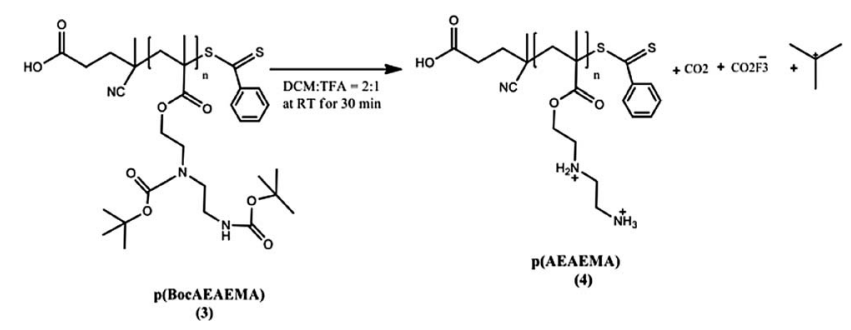

Scheme 3 Deprotection of poly[2-((tert-butoxycarbonyl)(2-((tertbutoxycarbonyl)amino)ethyl)amino)ethylmethacrylate) (P(BocAEAEMA) (3) to yield poly(2-(aminoethyl)amino)ethylmethacrylate], P(AEAEMA) (4).
The $M_{\mathrm{n}}$ (NMR) of the resultant polymers after deprotection was calculated theoretically, considering that all Boc groups were removed from the polymers. Thus the resultant deprotected polymers $\mathrm{P}(\mathrm{AEAEMA})$ having a $M_{\mathrm{n} \text {,theo after deprotection of }}$ $5500 \mathrm{Da}(\mathrm{DP}=32), 8000 \mathrm{Da}(\mathrm{DP}=44)$ and $10000 \mathrm{Da}(\mathrm{DP}=55)$ were used for further experiments.

Chain extension of the $\mathbf{P}($ BocAEAEMA) macro-RAFT agent with ManAc. $\mathrm{P}$ (BocAEAEMA) (30 $\mathrm{mg}, 0.0058 \mathrm{mmol}$ ) was used as a macro-RAFT agent and dissolved in DMF ( $2 \mathrm{ml})$. The ManAc glycomonomer (111.5 mg, $0.3 \mathrm{mmol}$ ) and AIBN (0.095 mg, $0.0057 \mathrm{mmol}$ ) were added into the solution. The reaction solution was transferred into a Schlenk tube. The solution was degassed by gentle bubbling of nitrogen for 20 minutes and then placed into an oil bath at $70{ }^{\circ} \mathrm{C}$ for 12 hours. The reaction was stopped via exposure to air and then the reaction mixture was dialysed against methanol-water mixture for two days. Finally, methanol was removed using a rotary evaporator and the residue mixture was freeze-dried to obtain the block copolymer (Scheme 2).

For deprotection of amino groups, P(BocAEAEMA) $)_{13}-b$ $\mathrm{P}(\text { ManAc })_{7}\left(M_{\mathrm{n}, \mathrm{GPC}}\right)=6850 \mathrm{Da}$; PDI $\left.=1.18\right)(10 \mathrm{mg})$ was dissolved in trifluoroacetic acid (TFA) $(0.5 \mathrm{ml})$ at $0{ }^{\circ} \mathrm{C}$. The final solution was stirred for $10 \mathrm{~min}$ at room temperature. TFA was removed by purging $\mathrm{N}_{2}$ at room temperature. The reaction mixture was then washed with diethyl ether and chloroform more than three times and finally the sample was dried in a vacuum oven. The deprotection process was verified by ${ }^{1} \mathrm{H}-\mathrm{NMR}$ spectroscopy using $\mathrm{D}_{2} \mathrm{O}$ as a solvent (data not shown). The $M_{\mathrm{n}}$ of the resultant polymer after deprotection was calculated theoretically, considering that all Boc groups were removed from the polymer. The resultant deprotected polymer (P(AEAEMA) $)_{13}-b$ -

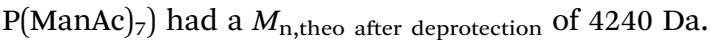

Determination of the proton sponge capacity of P(AEAEMA). The proton sponge capacity of deprotected polymers was determined in comparison with a well-known polycation used in intracellular drug delivery, i.e. polyethyleneimine (branched, $M_{\mathrm{n}}: 25 \mathrm{kDa}$ and $60 \mathrm{kDa}$; and linear, $M_{\mathrm{n}}: 8 \mathrm{kDa}$ ). A protocol reported previously ${ }^{31}$ was followed for determination of the proton sponge capacity of polymers. In these experiments, either the molar concentration of polymers or the repeating units in polymers were kept constant to be able to compare the proton sponge capacity of different types of polymers tested (i.e. P(AEAEMA) and PEI having varying molecular weights). Firstly, aqueous solutions of polymers ([polymer] $=2.2 \times$ $10^{-5} \mathrm{M}$ or [repeating unit] $=2.9 \times 10^{-4} \mathrm{M}$, in $10 \mathrm{ml}$ ) were prepared and the $\mathrm{pH}$ of the solutions was adjusted to $\mathrm{pH} 12$ by adding $\mathrm{NaOH}(40 \%, \mathrm{w} / \mathrm{v})$. The final solution was then titrated by addition of $\mathrm{HCl}$ solution $(0.1 \mathrm{M})$ until the $\mathrm{pH}$ of the solution decreased to 2 . The $\mathrm{pH}$ of solutions was monitored using a Hanna pH lab meter.

Determination of the in vitro cytotoxicity of P(AEAEMA). 3-(4,5-Dimethylthiazol-2-yl)-2,5-diphenyl tetrazolium bromide (MTT) cell viability assay was used to observe the effects of $\mathrm{P}(\mathrm{AEAEMA})\left(M_{\mathrm{n} \text {, theo after deprotection }}=5500 \mathrm{Da}\right.$, PDI: $1.35,(\mathrm{DP}=$ $32), M_{\mathrm{n} \text {,theo after deprotection }}=8000 \mathrm{Da}, \mathrm{PDI}: 1.41(\mathrm{DP}=44)$ and $M_{\text {n,theo after deprotection }}=10000 \mathrm{Da}(\mathrm{DP}=55)$, PDI: 1.40$)$ on the viability of the mouse fibroblast NIH 3T3 cell line. The MTT 
assay measures the ability of living cells to reduce a tetrazolium dye to insoluble formazan giving a purple colour. The cytotoxic effect of PEI (branched, 25000 and $60000 \mathrm{Da}$; and linear, 8000 $\mathrm{Da})$ was also determined in parallel to $\mathrm{P}$ (AEAEMA) for comparison.

Prior to cytotoxicity assays, the thiocarbonylthio RAFT-end group of P(AEAEMA) was removed from the polymers in order to avoid possible cytotoxicity of these active groups. ${ }^{45}$ To remove the RAFT-end group, protocols well-known in the literature have been performed. ${ }^{46,47}$ Briefly, P(AEAEMA) (1 eq.) dissolved in methanol was reacted with the 2-((2-aminoethyl) amino)ethylmethacrylate monomer (AEAEMA) (3 eq.) in the presence of hexylamine (HEA) (10 eq.) and triethylamine (TEA) (10 eq.) for 3 hours under a $\mathrm{N}_{2}$ atmosphere at room temperature. The aminolysis kinetics was monitored via UV-vis spectroscopy by scanning the absorbance in the range between 200 and $600 \mathrm{~nm}$. After reaction, the solvent was removed under vacuum. The polymer was precipitated in diethyl ether and then dried under vacuum. The product was characterized by ${ }^{1} \mathrm{H}$-NMR spectroscopy in $\mathrm{D}_{2} \mathrm{O}$. Polymers were further purified by dialysis against water using a membrane with a MW cut off 500-1000 Da for three days. The resultant polymers were then dried using a freeze-dryer and then characterized using ${ }^{1} \mathrm{H}$ NMR spectroscopy in $\mathrm{D}_{2} \mathrm{O}$ to ensure the complete removal of impurities. Separately, P(BocAEAEMA) $\left(M_{\mathrm{n}}=11 \mathrm{kDa}\right)$ was aminolyzed using the same procedure and purified by precipitation in hexane. The final product was characterized using ${ }^{1} \mathrm{H}$-NMR spectroscopy in DMSO- $\mathrm{d}_{6}$ to check whether there was any transesterification side reaction occurred under the aminolysis conditions applied.

In cytotoxicity analysis, NIH 3T3 cells were seeded a day before to polymer sample exposure at 10000 cells per well (96-well plate) in culture medium containing 10\% FBS-DMEM. Polymer sample stocks were prepared in PBS solution and $5 \mu \mathrm{l}$ of polymer solution was added at predetermined concentrations to cells. The cells were incubated at $37^{\circ} \mathrm{C} / 5 \% \mathrm{CO}_{2}$ for 24 or $72 \mathrm{~h}$. The culture medium was removed from the wells after the incubation period. The solution of MTT dye was prepared with culture medium $(10 \% \mathrm{v} / \mathrm{v})$. MTT solution $(100 \mu \mathrm{l})$ was added to wells according to the manufacturer's protocol. The plates were incubated at $37^{\circ} \mathrm{C}$ for another $4 \mathrm{~h}$. After $4 \mathrm{~h}$, the 96-well plate was centrifuged at $1800 \mathrm{rpm}$ for $10 \mathrm{~min}$, MTT solution was then removed. DMSO $(100 \mu \mathrm{l})$ was added to wells to dissolve the crystals. In order to detect metabolic activity, the absorbance of the solutions was recorded at $540 \mathrm{~nm}$ using a microplate reader. The cell viability (\%) was calculated relative to the positive control (cells not treated with polymers) according to eqn (3) in which $A_{\text {cell+sample }}$ is the absorbance of the cells treated with polymer and $A_{\text {positive control }}$ is the absorbance of the nontreated cells.

$$
\text { Cell viability } \%=\frac{A_{\text {cell }+ \text { sample }}}{A_{\text {positive control }}} \times 100
$$

Determination of polyplex formation by agarose gel electrophoresis. In order to determine DNA binding ability of $\mathrm{P}(\mathrm{AEAEMA})\left(M_{\mathrm{n}, \text { theo after deprotection }}=5500 \mathrm{Da}(\mathrm{DP}=32), 8000\right.$
$\mathrm{Da}(\mathrm{DP}=44)$ and $10000 \mathrm{Da}(\mathrm{DP}=55))$ and P(AEAEMA $)_{13}-b$ $\mathrm{P}(\mathrm{ManAc})_{7}\left(M_{\mathrm{n}, \text { theo after deprotection }}=4240 \mathrm{Da}\right)$, polymers were complexed with 700 bp DNA at three different nitrogen/ phosphate (N/P) ratios (20/1, 10/1 and 2/1). Polymers were dissolved at an appropriate concentration in phosphatecitrate buffer at pH $5.5(8 \mu \mathrm{l})$ and mixed with DNA solution in Tris-EDTA buffer (33 ng $\mu \mathrm{l}^{-1}, 1.8 \mu \mathrm{l}$ ). Polymer-DNA solutions were incubated at room temperature for $15 \mathrm{~min}$ and then loaded into $1 \%$ agarose gel stained with ethidium bromide. The gel was run at $100 \mathrm{~V}$ for 55 min using TAE as a running buffer. For comparison, the polyplex formation was also investigated using PEI (25 $000 \mathrm{Da}$ ) following the same procedures given above.

Determination of the polyplex size by dynamic light scattering (DLS). The polyplexes were formed at a N/P ratio of 20 according to the procedure described above. Polymer solution at an appropriate concentration in phosphate-citrate buffer at pH $5.5(24 \mu \mathrm{l})$ was added into DNA solution in Tris-EDTA buffer (33 ng $\mu \mathrm{l}^{-1}, 5.46 \mu \mathrm{l}$ ). The final polyplex solution was diluted to $986.5 \mu \mathrm{l}$ with ultrapure water. The polyplexes were incubated for 15 min before particle size analysis. Each sample was analyzed three times for 72 and/or 30 runs.

\section{Results and discussion}

Synthesis of 2-((tert-butoxycarbonyl)(2-((tert-butoxycarbonyl)amino)ethyl)amino)ethylmethacrylate

A new, spermine-like amine containing monomer, 2-((tertbutoxycarbonyl)(2-((tert-butoxycarbonyl)amino)ethyl)amino)ethyl methacrylate was first synthesized. The synthesis procedure was composed of two steps. The first step was to protect the primary and secondary amine groups of $N$-hydroxyethylethylenediamine in order to prevent any possible unwanted side reactions. The amine groups were protected using di-tert-butyl dicarbonate (Boc) based on a method reported by Moura et al. ${ }^{41}$ The Boc group has been widely used in peptide synthesis for protection of $\alpha$ - and side chain-amine groups of amino acids. ${ }^{1} \mathrm{H}-\mathrm{NMR}$ spectra of $\mathrm{N}$-hydroxyethylethylenediamine before and after protection are shown in Fig. S14 (ESI). $\dagger$ The characteristic chemical shift of amine groups in $N$-hydroxyethylethylenediamine at $2.20 \mathrm{ppm}$ disappeared completely after the protection process. The characteristic proton signals of the Boc group appeared clearly between 1.39 and $1.49 \mathrm{ppm}$.

In the second step, the amine-protected product, tertbutyl (2-((tert-butoxycarbonyl)amino)ethyl)(2-hydroxyethyl)carbamate, was reacted with methacryloyl chloride to prepare the final methacrylate monomer following a method reported elsewhere. ${ }^{\mathbf{4 2 , 4 3}}$ The yield of the reaction was determined to be $84 \%$ from the ${ }^{1} \mathrm{H}$-NMR spectrum of the reaction mixture (Fig. S15, ESI $\dagger)$. The final pure product, 2-((tert-butoxycarbonyl)(2-((tert-butoxycarbonyl)amino)ethyl)amino)ethyl methacrylate (BocAEAEMA), obtained after column chromatography was characterized by ${ }^{1} \mathrm{H}-\mathrm{NMR}$ spectroscopy (Fig. 1). The characteristic signals of vinyl protons, $-\mathrm{CH}_{2}$ and $-\mathrm{CH}_{3}$, were observed at $6.11 \mathrm{ppm}(1 \mathrm{H}), 5.58 \mathrm{ppm}(1 \mathrm{H})$ and $1.94 \mathrm{ppm}(3 \mathrm{H})$, respectively. Upon methacrylation, the signal 


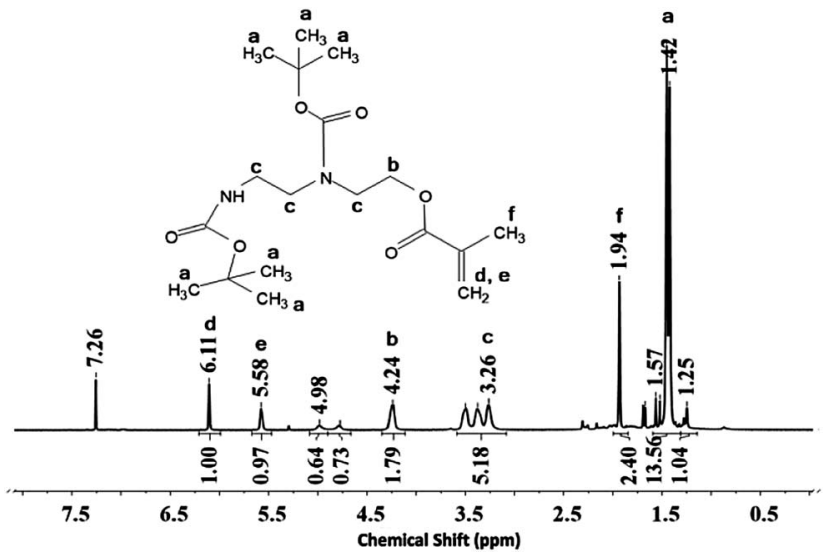

Fig. $1{ }^{1} \mathrm{H}$-NMR spectrum of pure 2-((tert-butoxycarbonyl)(2-((tertbutoxycarbonyl)amino)ethyl)amino)ethyl methacrylate (BocAEAEMA) obtained after column chromatography.

of protons of $-\mathrm{CH}_{2}$ - adjacent to the $-\mathrm{OH}$ group in tert-butyl(2-((tert-butoxycarbonyl)amino)ethyl)(2-hydroxyethyl)carbamate, which was located at 3.71 ppm (Fig. S14, ESI $\dagger$ ) clearly shifted to 4.25-4.23 ppm in the final product (Fig. 1) indicating the formation of an ester bond $\left(-\mathrm{CH}_{2}-\mathrm{CH}_{2}-\mathrm{O}-\mathrm{C}(=\mathrm{O})-\right)$.

\section{RAFT polymerization of BocAEAEMA}

2-((tert-Butoxycarbonyl)(2-((tert-butoxycarbonyl)amino)ethyl)amino)ethyl methacrylate (BocAEAEMA) was polymerized via RAFT polymerization using 4-cyano-4-(phenylcarbonothioylthio) pentanoic acid (CPADB) as a RAFT agent. CPADB has been widely used as a RAFT agent in controlling the polymerization of methacrylates. ${ }^{48}$ RAFT polymerization kinetics were investigated at varying [monomer]/[RAFT agent] ratios $([\mathrm{M}] /[\mathrm{R}]: 25 / 1,50 / 1$ and $100 / 1)$ at a fixed monomer concentration of $0.72 \mathrm{M}$ or at a fixed initiator concentration of $3.6 \times 10^{-3} \mathrm{M}$. In all polymerizations the ratio of the RAFT agent concentration to the initiator concentration $([\mathrm{R}] /[\mathrm{I}])$ was kept constant at $1 / 0.25$. Monomer conversion was calculated from ${ }^{1} \mathrm{H}-\mathrm{NMR}$ spectra of polymerization mixtures (Fig. S16, ESI $\dagger$ ). The number average molecular weights $\left(M_{\mathrm{n}}\right)$ and polydispersity indices (PDI) of the synthesized polymers were determined by gel permeation chromatography. The $M_{\mathrm{n}}$ s were also determined by NMR spectroscopy.

Table S1 (ESI $\dagger$ ) shows the conversion, $M_{\mathrm{n}}$ and PDI values of the polymers synthesized at a constant monomer concentration of $0.72 \mathrm{M}$ with varying $[\mathrm{M}] /[\mathrm{R}] /[\mathrm{I}]$ ratios. GPC chromatograms of polymerization mixtures showed the increase in molecular weight with time and the presence of monomodal distributions (Fig. S17, ESI $\dagger$ ). The increase in monomer conversion and $[\mathrm{M}] /[\mathrm{R}]$ ratio led to an increase in $M_{\mathrm{n}}$ values. The PDI values were below 1.36 for all polymerizations. In all polymerizations, ln $[\mathrm{M}]_{\mathrm{o}} /[\mathrm{M}]$ increased linearly with time (Fig. 2), indicating pseudofirst order behaviour of polymerization. The linear increase in $M_{\mathrm{n}}$ with monomer conversion was also observed (Fig. 2). These are all attributed to the known traits of the RAFT-controlled polymerization mechanism. ${ }^{34,35}$
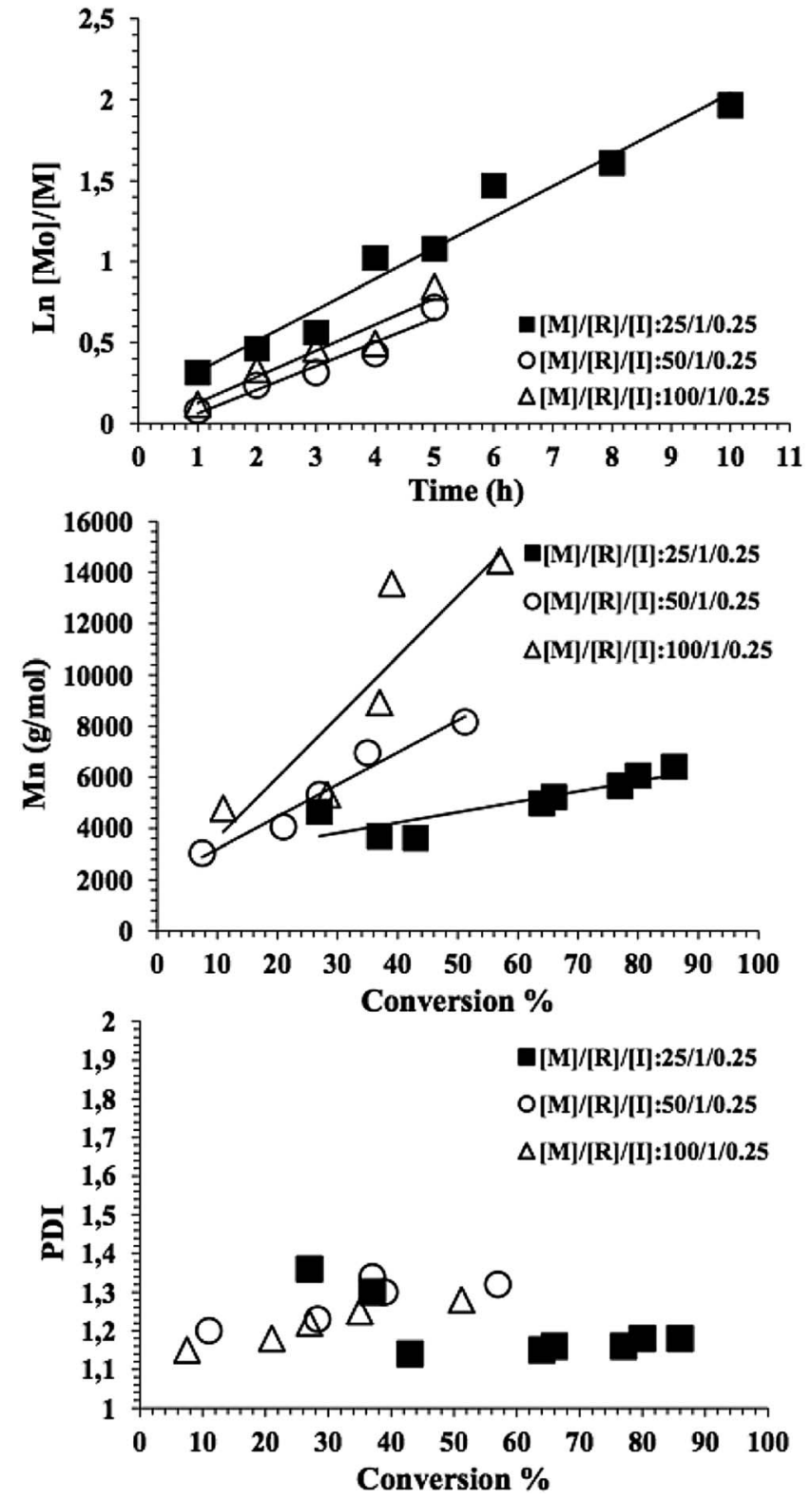

Fig. 2 Kinetic plots of RAFT polymerization of BocAEAEMA performed at a monomer concentration of $0.72 \mathrm{M}$ and varying ratios of $[\mathrm{M}] /[\mathrm{R}] /[\mathrm{l}]$.

Table S1 (ESI $\dagger$ ) and Fig. 3 present the effects of the $[\mathrm{M}] /[\mathrm{R}]$ ratio on the RAFT polymerization of BocAEAEMA performed at a constant initiator concentration of $3.6 \times 10^{-3} \mathrm{M}$ and a $[\mathrm{R}] /[\mathrm{I}]$ ratio of 4 . The $[\mathrm{M}] /[\mathrm{R}]$ ratio, thus the monomer concentration, was varied to be $25 / 1(0.36 \mathrm{M}), 50 / 1(0.72 \mathrm{M})$ or 100/1 (1.44 M). Similar results indicating the RAFT-controlled polymerization mechanism were obtained. The increase in the monomer concentration led to an increase in free radical polymerization rate, as expected. ${ }^{49}$ The kinetic plots revealed the linear proportionality between $\ln [\mathrm{M}]_{\mathrm{o}} /[\mathrm{M}]$ and polymerization time, and $M_{\mathrm{n}}$ and conversion, proving the RAFTcontrolled mechanism. However, side reactions might have occurred with the increase in $[\mathrm{M}] /[\mathrm{R}]$ ratio, leading to significantly larger PDI values. 

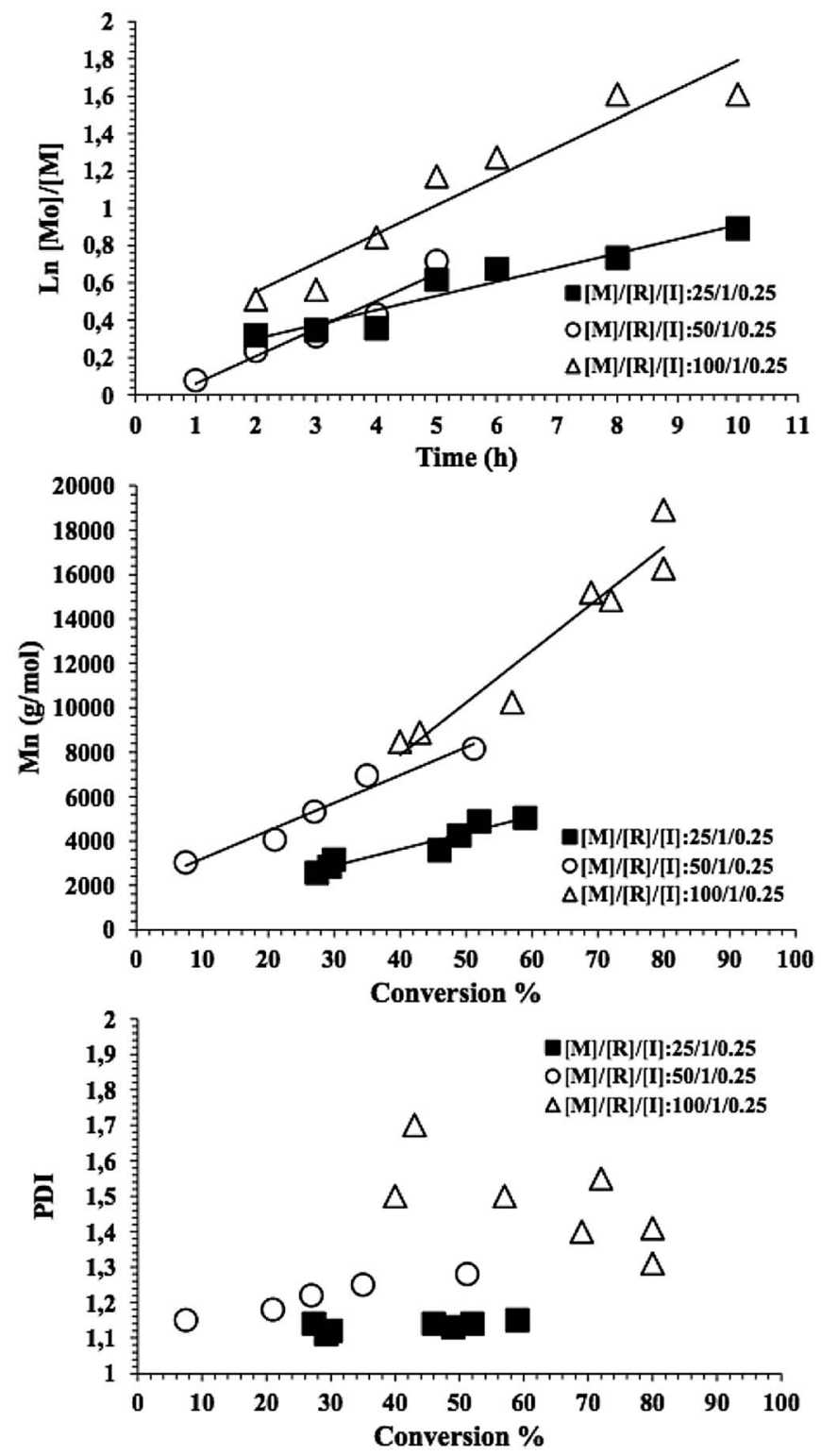

Fig. 3 Kinetic plots of RAFT polymerization of BocAEAEMA performed at an initiator concentration of $3.6 \times 10^{-3} \mathrm{M}$ and varying ratios of $[\mathrm{M}] /$ $[R] /[1]$.

Overall results showed that the polymerization of a new monomer, BocAEAEMA, in toluene using AIBN as an initiator and CPADB as a RAFT agent displayed all characteristics of the RAFT-controlled polymerization mechanism.

A representative ${ }^{1} \mathrm{H}-\mathrm{NMR}$ spectrum of purified $\mathrm{P}$ (BocAEAEMA) synthesized at a monomer concentration of $1.44 \mathrm{M}$ and $\mathrm{a}[\mathrm{M}] /[\mathrm{R}] /[\mathrm{I}]$ ratio of $100 / 1 / 0.25$ (conversion $=80 \%$, $M_{\mathrm{n}, \mathrm{GPC}}=19000 \mathrm{Da}$, PDI $=1.31$ ) is given in Fig. 4(A). The spectrum shows all signals expected for the polymer structure, proving the successful synthesis of P(BocAEAEMA) by RAFT polymerization.

Prior to proton sponge and cytotoxicity experiments, polymers were deprotected to yield the final amine-containing spermine-like polymer structures. Fig. 4(B) shows the NMR

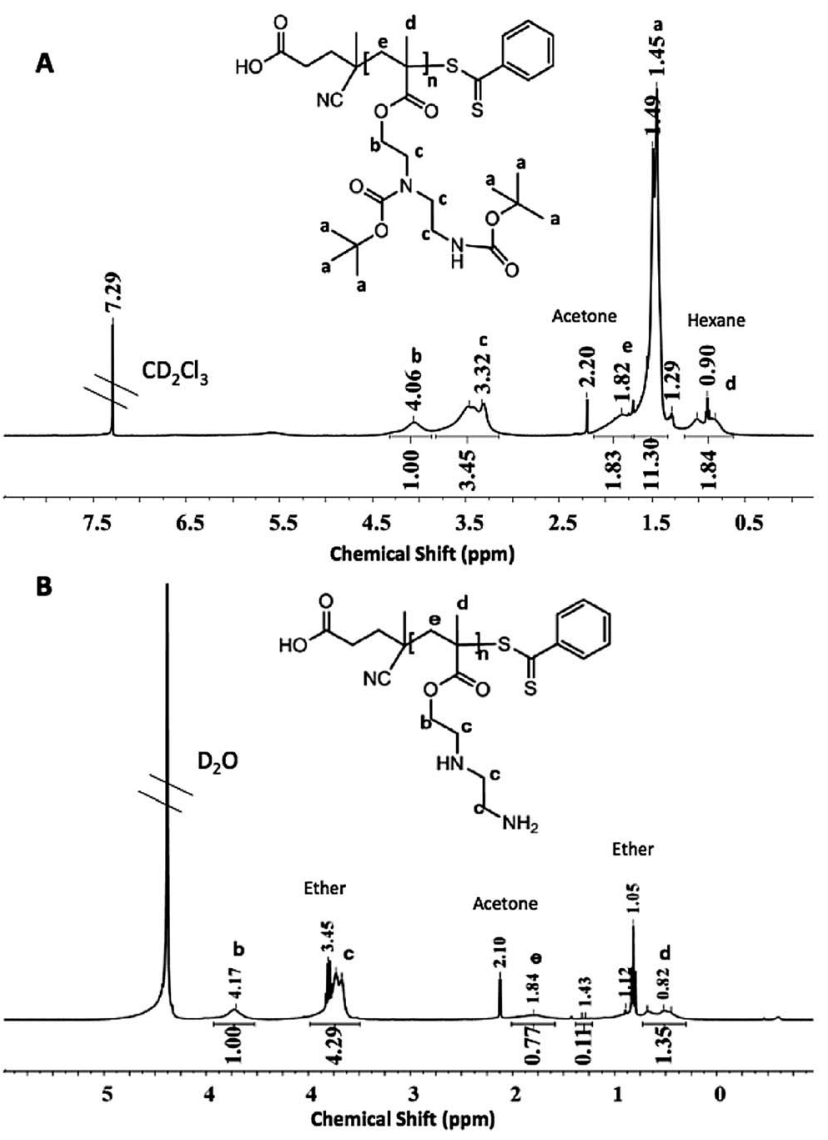

Fig. $4{ }^{1} \mathrm{H}-\mathrm{NMR}$ spectrum of (A) 2-((tert-butoxycarbonyl)(2-((tertbutoxycarbonyl)amino)ethyl)amino)ethyl methacrylate polymer, $\mathrm{P}$ (BocAEAEMA), synthesized at a monomer concentration of $1.44 \mathrm{M}$, $[\mathrm{M}] /[\mathrm{R}] /[\mathrm{l}]$ ratio of $100 / 1 / 0.25$ (conversion $=80 \%, M_{\mathrm{n}, \mathrm{GPC}}=19000 \mathrm{Da}$, $\mathrm{PDI}=1.31)$, and $(\mathrm{B})$ after deprotection of the same polymer yielding P(AEAEMA).

spectrum of a polymer synthesized at a monomer concentration of $1.44 \mathrm{M}$ and $\mathrm{a}[\mathrm{M}] /[\mathrm{R}] /[\mathrm{I}]$ ratio of $100 / 1 / 0.25$ (conversion $=80 \%$, $M_{\mathrm{n}, \mathrm{GPC}}=19000 \mathrm{Da}, \mathrm{PDI}=1.31$ ) obtained after deprotection and purification. It should be noted that the NMR spectrum of the deprotected polymer was taken in $\mathrm{D}_{2} \mathrm{O}$ since the polymer solubility after removal of Boc groups changed dramatically, indicating the enhanced polarity of the deprotected polymer. The proton signals of Boc groups normally appear at 1.40 and $1.48 \mathrm{ppm}$ completely disappeared in the spectrum of the deprotected polymer, showing that the polymer amine groups were fully deprotected, yielding P(AEAEMA). Molecular weights of polymers after deprotection were calculated theoretically by subtracting the mass of Boc protection groups from the mass of polymers determined by NMR.

\section{Synthesis of P(BocAEAEMA)- $b$-P(ManAc)}

In order to enhance the biocompatibility and serum stability of polyplex particles to be formed with $\mathrm{P}$ (AEAEMA) and DNA and more importantly give the particles specific cell-recognition ability, block copolymers of P(BocAEAEMA) with a model sugar block, poly(mannose-acrylate) $\mathrm{P}(\mathrm{ManAc})$, were prepared. The 
ManAc glycomonomer was directly polymerized using $\mathrm{P}$ (BocAEAEMA) as a macro-RAFT agent. This approach is relatively straightforward as there is no need of post-polymerization modifications. The final product was characterized by ${ }^{1} \mathrm{H}$ NMR and GPC, as illustrated in Fig. 5. GPC chromatograms showed the chain extension of the $\mathrm{P}$ (BocAEAEMA) macro-RAFT agent with ManAc monomer. The ${ }^{1} \mathrm{H}$ NMR spectrum of the block copolymer clearly showed the proton signals of the $\mathrm{P}(\mathrm{ManAc})$ block. Prior to DNA complexation experiments, $\mathrm{P}(\text { BocAEAEMA })_{13}-b-\mathrm{P}(\text { ManAc })_{7}$ was deprotected and characterized by ${ }^{1} \mathrm{H}$ NMR spectroscopy (data not shown). The deprotection was verified by the complete disappearance of the proton signals of Boc groups, normally appearing at $1.35 \mathrm{ppm}$ in the ${ }^{1} \mathrm{H}-\mathrm{NMR}$ spectrum of $\mathrm{P}(\text { BocAEAEMA })_{13}-b-\mathrm{P}(\text { ManAc })_{7}$ (in DMSO- $\mathrm{d}_{6}$ ) before deprotection. The molecular weight of $\mathrm{P}(\text { AEAEMA })_{13}-b-\mathrm{P}(\mathrm{ManAc})_{7}$ was calculated theoretically by subtracting the mass of Boc protection groups from the molecular weight of $\mathrm{P}(\text { BocAEAEMA })_{13}-b$-P(ManAc $)_{7}$ determined by GPC and found to be 4240 Da.

\section{Proton sponge capacity of P(AEAEMA)}

$\mathrm{P}$ (BocAEAEMA) synthesized at a monomer concentration of $1.44 \mathrm{M}$ and $\mathrm{a}[\mathrm{M}] /[\mathrm{R}] /[\mathrm{I}]$ ratio of $200 / 1 / 0.25$ for $5-10 \mathrm{~h}\left(M_{\mathrm{n}, \mathrm{GPC}}=\right.$ $11500 \mathrm{Da}, \mathrm{PDI}=1.35, M_{\mathrm{n}, \mathrm{NMR}}=12000 \mathrm{Da}, \mathrm{DP}=32 ; M_{\mathrm{n}, \mathrm{GPC}}=$ $13500 \mathrm{Da}, \mathrm{PDI}=1.41, M_{\mathrm{n}, \mathrm{NMR}}=16500 \mathrm{Da}, \mathrm{DP}=44 ; M_{\mathrm{n}, \mathrm{GPC}}=$ $23500 \mathrm{Da}, \mathrm{PDI}=1.40, M_{\mathrm{n}, \mathrm{NMR}}=20400 \mathrm{Da}, \mathrm{DP}=55$ ) were used in experiments performed to determine proton sponge capacity and cytotoxicity. The molecular weight of these polymers after deprotection $\left(M_{\mathrm{n} \text {,after deprotection }}\right)$ was $5500 \mathrm{Da}(\mathrm{DP}=32), 8000 \mathrm{Da}$ $(\mathrm{DP}=44)$ and $10000 \mathrm{Da}(\mathrm{DP}=55)$, respectively.

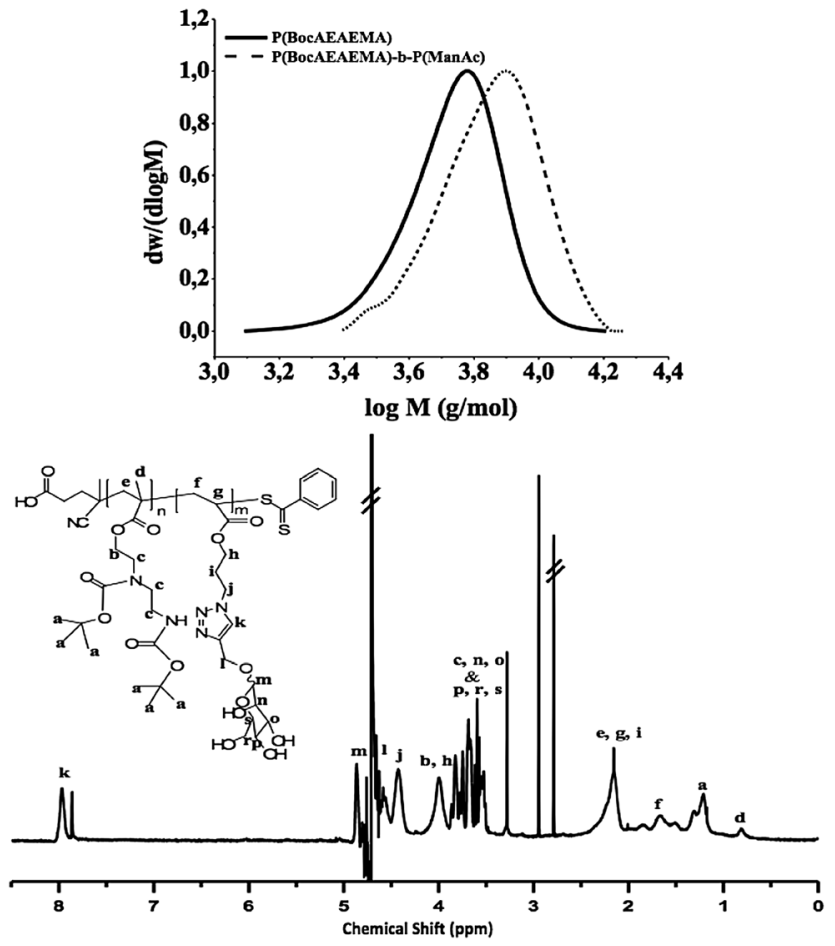

Fig. 5 Representative GPC chromatogram and ${ }^{1} \mathrm{H}$ NMR spectrum of the prepared $\mathrm{P}(\mathrm{AEAEMA})-b-\mathrm{P}(\mathrm{ManAc})$ block copolymer.
The proton sponge capacity of $\mathrm{P}(\mathrm{AEAEMA})$ was investigated in comparison to polyethyleneimine (PEI), a widely used polymer in intracellular drug delivery because of its high buffering capacity. ${ }^{13-17} \mathrm{P}$ (AEAEMA) having a $M_{\mathrm{n}}$, after deprotection of $5.5 \mathrm{kDa}$, $8 \mathrm{kDa}$ and $10 \mathrm{kDa}$ and branched PEI of $25 \mathrm{kDa}$ and $60 \mathrm{kDa}$, and linear PEI of $8 \mathrm{kDa}$ were first titrated with $0.1 \mathrm{M} \mathrm{HCl} \mathrm{using}$ polymer solutions containing the same repeating unit concentration $\left(2.9 \times 10^{-4} \mathrm{M}\right)$ in order to eliminate the effect of molecular weight differences between different polymers.

The titration curves obtained at the same repeating unit concentration are presented in Fig. 6. When the differences in the molecular weight of different polymers were eliminated, the buffering capacity of P(AEAEMA) was found to be comparable with that of PEI, a highly efficient proton sponge polymer. While branched PEI (25 kDa) and linear PEI (8 kDa) required $53 \pm 1$ and $65 \mathrm{~mole} \mathrm{HCl} / \mathrm{mole}$ repeating unit, respectively, P(AEAEMA) having $M_{\mathrm{n}}$ of $10 \mathrm{kDa}$ and $8 \mathrm{kDa}$ required $56 \pm 1$ and $58 \pm 4$ mole $\mathrm{HCl}$ per mole repeating unit, respectively, to drop the $\mathrm{pH}$ to acidic $\mathrm{pH}$ values (Table 1). Although the repeating unit of branched PEI contains a 3.5-4.0-fold higher number of primary and/or secondary amine groups than that of P(AEAEMA), the titration results suggest that the protonation of PEI repeating units is possibly affected by the polyprotic nature of the molecule. In polyprotic acids/bases, the deprotonation/protonation of one of the closely associated acid/base groups inhibits further proton dissociation/association from/to the same molecule. ${ }^{50}$ The titration results clearly suggest that P(AEAEMA) potentially offers a proton sponge effect comparable to PEI, which strongly encourages the investigations on the use of $\mathrm{P}$ (AEAEMA) as an endosomal-escaping agent.

Titrations were repeated using polymer solutions having the same molar concentration $\left(2.2 \times 10^{-5} \mathrm{M}\right)$ (Fig. 7). As expected, the proton sponge capacity decreased with the decrease in the molecular weight of polymers when the same molar concentration solutions of polymers of varying molecular weights were used. In the case of higher molecular weight branched PEIs (25 $\mathrm{kDa}$ and $60 \mathrm{kDa}$ ), since the solutions contained a higher

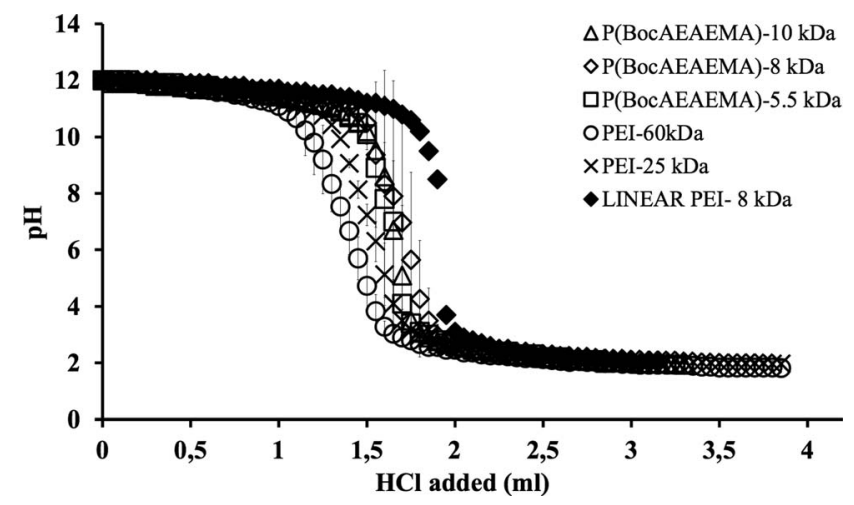

Fig. 6 Proton sponge capacity of P(AEAEMA) $(5.5,8$ and $10 \mathrm{kDa})$ and $\mathrm{PEI}$ (branched; $25 \mathrm{kDa}$ and $60 \mathrm{kDa}$, and linear $8 \mathrm{kDa}$ ). The repeating unit concentration in all polymer solutions was kept the same $(2.9 \times$ $\left.10^{-4} \mathrm{M}\right)$. The results are the average of three different experiments (with the exception that the experiments with P(AEAEMA) having a $M_{n}$ of 5500 Da and PEl having a $M_{n}$ of 8000 Da were performed once). 
Table 1 Proton sponge capacity of polymers

\begin{tabular}{lcl}
\hline Polymers & $\begin{array}{l}\text { HCl/polymer (mole } \\
\text { ratio) }\end{array}$ & $\begin{array}{l}\text { HCl/repeat unit } \\
\text { (mole ratio) }\end{array}$ \\
\hline PEI (60 kDa) & $1230 \pm 21$ & $47 \pm 2$ \\
PEI $(25 \mathrm{kDa})$ & $867 \pm 53$ & $53 \pm 1$ \\
PEI (8 kDa) & 877 & 65 \\
P(AEAEMA) (10 kDa) & $757 \pm 26$ & $56 \pm 1$ \\
P(AEAEMA) (8 kDa) & $601 \pm 34$ & $58 \pm 4$ \\
P(AEAEMA) (5.5 kDa) & $192 \pm 26$ & 55
\end{tabular}

number of amine-containing repeating units, a higher amount of $\mathrm{HCl}$ was needed to drop the $\mathrm{pH}$ of the PEI solutions, when compared with the solutions of P(AEAEMA) having molecular weights ranging from $5.5 \mathrm{kDa}$ to $10 \mathrm{kDa}$. A linear PEI of $8 \mathrm{kDa}$ displayed higher proton sponge capacity than P(AEAEMA) of 8 $\mathrm{kDa}$. The linear PEI solution contains a higher number of protonable amine groups than the solution of P(AEAEMA) at the same concentration since the DP of linear PEI of $8 \mathrm{kDa}$ is approximately 186, while the DP of P(AEAEMA) of the same molecular weight is 44 .

\section{In vitro cytotoxicity of $\mathrm{P}$ (AEAEMA)}

Before performing the cytotoxicity assays, the thiocarbonylthio RAFT end-group of $\mathrm{P}(\mathrm{AEAEMA})$ was removed as this reactive group might possess toxic effects on living cells. According to the study of Pissuwan et al., ${ }^{45}$ polymers synthesized via RAFT polymerization using 4-cyano-4-(phenylcarbonothioylthio) pentanoic acid as a RAFT agent have no toxicity on NIH 3T3 and CHO-K1 cell lines over 72 h. However, the same study showed that the RAFT end-group cytotoxicity depends on the types of cell line and polymer. In order to avoid any possible toxic effects of the RAFT end-group, the thiocarbonylthio end group of polymers was cleaved to thiol in the presence of hexylamine, triethylamine and AEAEMA monomer, following a procedure

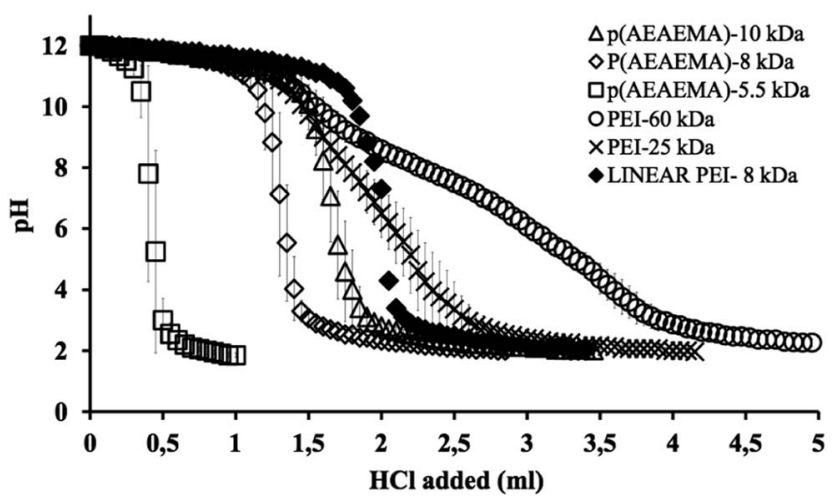

Fig. 7 Proton sponge capacity of P(AEAEMA) (5.5, 8 and $10 \mathrm{kDa})$ and PEI (branched; $25 \mathrm{kDa}$ and $60 \mathrm{kDa}$, and linear $8 \mathrm{kDa}$ ). The polymer concentration in all polymer solutions was kept the same $(2.2 \times$ $\left.10^{-5} \mathrm{M}\right)$. The results are the average of three different experiments (with the exception that the experiments with P(AEAEMA) having a $M_{n}$ of $5500 \mathrm{Da}$ and PEl having a $M_{\mathrm{n}}$ of 8000 Da were performed twice and once, respectively). reported previously in the literature. ${ }^{\mathbf{4 6 , 4 7}}$ The ${ }^{1} \mathrm{H}$-NMR and UV-vis spectra of $\mathrm{P}\left(\right.$ AEAEMA) $\left(M_{\mathrm{n}}\right.$, after deprotection $\left.=5.5 \mathrm{kDa}\right)$ after aminolysis are shown in Fig. S18 and S19 (ESI). $\uparrow$ Both the UV and ${ }^{1} \mathrm{H}$-NMR analyses showed that the RAFT end-group of the polymers was efficiently removed. Here it should be noted that the ${ }^{1} \mathrm{H}-\mathrm{NMR}$ analysis of the aminolyzed polymer in DMSO- $\mathrm{d}_{6}$ (Fig. S18 $\dagger$ ) showed that there was no transesterification reaction leading to the formation of poly(methyl methacrylate).

The effect of P(AEAEMA) $M_{\mathrm{n}}$, after deprotection $=5.5 \mathrm{kDa}(\mathrm{DP}=$ $32), 8 \mathrm{kDa}(\mathrm{DP}=44)$, and $10 \mathrm{kDa}(\mathrm{DP}=55)$ on the viability of the in vitro cultured mouse fibroblast NIH 3T3 cell line was investigated using MTT cell viability assay. P(AEAEMA)s at varying concentrations $(0.1 \mu \mathrm{M}, 0.2 \mu \mathrm{M}, 0.4 \mu \mathrm{M}, 0.8 \mu \mathrm{M}$ and $1.6 \mu \mathrm{M})$ were incubated with cells for $24 \mathrm{~h}$ and $72 \mathrm{~h}$. For comparison, PEIs (branched, $25 \mathrm{kDa}$ and $60 \mathrm{kDa}$; and linear, $8 \mathrm{kDa}$ ) were also tested in the assays. The percentage of the cell viability was determined with respect to untreated cells (cells with no polymer treatment).

The MTT assay results showed that P(AEAEMA)s did not have any significant cytotoxic effect on NIH 3T3 cells at all polymer concentrations tested while PEIs $(25 \mathrm{kDa}$ and $60 \mathrm{kDa}$ ) were highly toxic at a concentration of $0.4 \mu \mathrm{M}$ and above even after

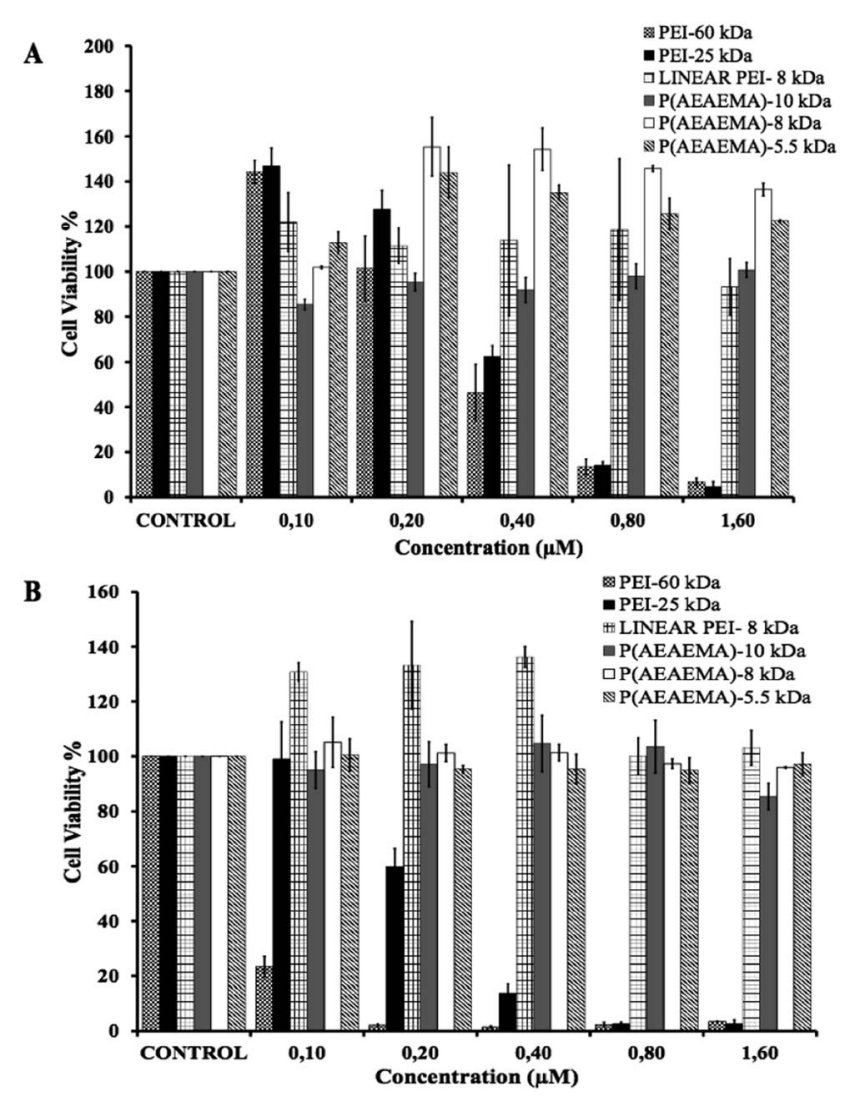

Fig. 8 Viability of NIH 3 T3 cells after incubation with P(AEAEMA) $\left(M_{\mathrm{n}}\right.$, after deprotection $=5.5 \mathrm{kDa}, 8 \mathrm{kDa}$, and $\left.10 \mathrm{kDa}\right)$ and PEl $(60 \mathrm{kDa}$ and $25 \mathrm{kDa}) \mathrm{s}$ for (A) $24 \mathrm{~h}$ and (B) $72 \mathrm{~h}$. Control is the cells with no treatment. The polymer mass concentrations ( $\mathrm{mg} \mathrm{L}^{-1}$ ) were as follows: $6,12,24$, 48, 96 for PEI $60 \mathrm{kDa}$; 2.5, 5, 10, 20, 40 for PEI $25 \mathrm{kDa} ; 1,2,4,8,16$ for P(AEAEMA) $10 \mathrm{kDa}$; $0.8,1.6,3.2,6.4,12.8$ for PEl and P(AEAEMA) $8 \mathrm{kDa}$; $0.55,1.1,2.2,4.4,8.8$ for P(AEAEMA) $5.5 \mathrm{kDa}$. 
$24 \mathrm{~h}$ incubation (Fig. 8). Similar to P(AEAEMA)s, linear PEI of $8 \mathrm{kDa}$ had also no toxic effect. The less toxic effect of P(AEAEMA) $\mathrm{S}$ and PEI $8 \mathrm{kDa}$ may be attributed to the fact that the solutions of the low molecular weight polymers (P(AEAEMA)s and PEI of $8 \mathrm{kDa}$ ) contain less number of amine groups when compared with the solutions of high molecular weight polymers (PEI $25 \mathrm{kDa}$ and $60 \mathrm{kDa}$ ) at the same molar concentrations. The cell viabilities above $100 \%$ might be due to the potential effect of amine-containing polymers on cell metabolism or an artificial side reaction of these polymers with assay reagents or products, which is usually tolerated for longer incubation times (e.g. $72 \mathrm{~h}){ }^{51}$

\section{Polyplex formation with DNA}

The ability of P(AEAEMA) and P(AEAEMA)- $b$-P(ManAc) to electrostatically complex with DNA was first tested by gel electrophoresis. $\mathrm{P}($ AEAEMA $) M_{\mathrm{n}}$, after deprotection $=5.5 \mathrm{kDa}(\mathrm{DP}=32)$ and $10 \mathrm{kDa}(\mathrm{DP}=55), \mathrm{P}(\text { AEAEMA })_{13}-b-\mathrm{P}(\mathrm{ManAc})_{7}\left(M_{\mathrm{n}}\right.$, after deprotection $=4.24 \mathrm{kDa})$ and PEI $(25 \mathrm{kDa})$ were incubated with a DNA fragment of $700 \mathrm{bp}$ at $\mathrm{pH} 5.5$ (where most amine groups on the polymers are estimated to be protonated) for 15 minutes. The complexations were performed at three different nitrogen (sourced from primary and secondary amine groups of polymers)/phosphorus (sourced from phosphate groups of DNA) $(\mathrm{N} / \mathrm{P})$ ratios $(20,10$ and 2$)$. As it can be seen in the gel electropherogram (Fig. 9), DNA was fully complexed with PEI at all N/P ratios tested, as evidenced by the absence of any free DNA band of $700 \mathrm{bp}$ (Lanes 2-4, Fig. 9). The same result was also observed with $\mathrm{P}(\mathrm{AEAEMA})_{32}$ having a $M_{\mathrm{n} \text {,after deprotection }}=5.5 \mathrm{kDa}$ (Lanes 8-10). In the case of $\mathrm{P}(\mathrm{AEAEMA})_{55}$ with $M_{\mathrm{n} \text {,after deprotection }}=$ $10 \mathrm{kDa}$, the DNA fragment could not be fully complexed with the polymer at a N/P ratio of 2 , while a complete complexation was observed at higher N/P ratios (Lanes 5-7). Overall these results proved that $\mathrm{P}$ (AEAEMA) was effective in forming polyplexes with a DNA fragment. Also a lower $M_{\mathrm{n}}$ polymer appeared to interact

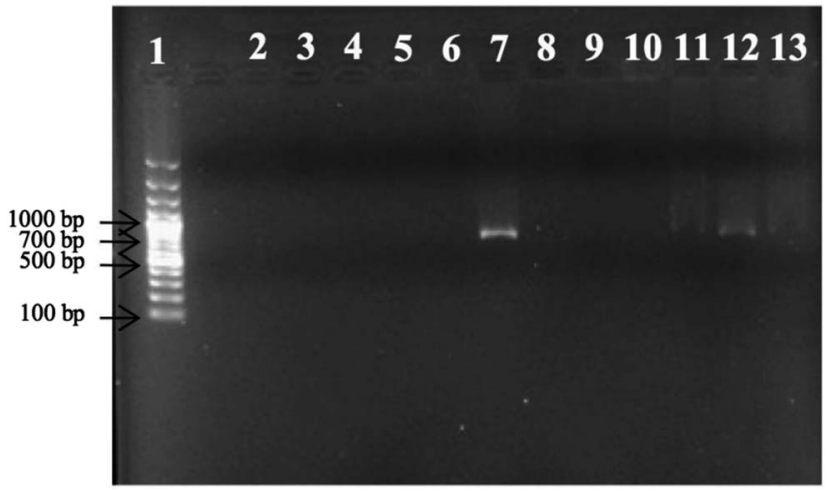

Fig. 9 Agarose gel electropherogram of polymer-DNA complexes. Lane 1: DNA markers; Lanes 2-4: PEI (25 kDa)-DNA complexes prepared at a N/P ratio of 20, 10 and 2, respectively; Lanes 5-7: $\mathrm{P}(\mathrm{AEAEMA})_{55}(10 \mathrm{kDa})-\mathrm{DNA}$ complexes prepared at a N/P ratio of 20 , 10, and 2, respectively; Lanes 8-10: P(AEAEMA) 32 (5 kDa)-DNA complexes prepared at a N/P ratio of 20,10, and 2, respectively; Lanes 11-13: $\quad$ (AEAEMA) $13-b-P(M a n A c)_{7} \quad(4.24 \mathrm{kDa})-D N A$ complexes prepared at a N/P ratio of 20,10 , and 2 , respectively.

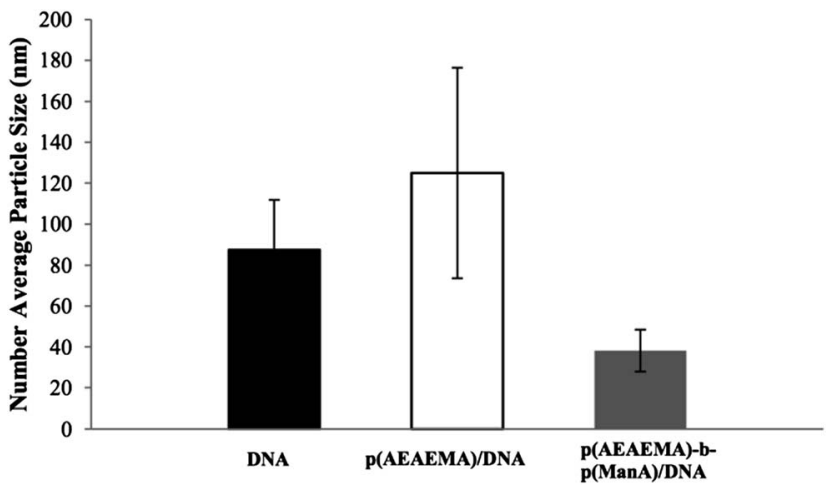

Fig. 10 The number average particle size of polymer-DNA complexes at an N/P ratio of 20 , determined by dynamic light scattering.

with a large DNA fragment easier than its higher $M_{\mathrm{n}}$ counterpart, probably due to the less steric hindrance effect. In the case of $\mathrm{P}(\text { AEAEMA })_{13}-b-\mathrm{P}(\mathrm{ManAc})_{7}$, a full complexation could not be observed at any of $\mathrm{N} / \mathrm{P}$ ratios tested (Lanes 11-13). The presence of the ManAc block clearly inhibited the interaction of the P(AEAEMA) block with DNA. However, from the band intensities, it was clear that the complexation increased with increasing $\mathrm{N} / \mathrm{P}$ ratio.

Finally, the hydrodynamic diameter of polyplexes formed by DNA and $\mathrm{P}(\text { AEAEMA })_{32}\left(M_{\mathrm{n} \text {,after deprotection }}=5500 \mathrm{Da}\right)$ or $\mathrm{P}(\text { AEAEMA })_{13}-b-\mathrm{P}(\text { ManAc })_{7}\left(M_{\mathrm{n} \text {,after deprotection }}=4240 \mathrm{Da}\right)$ at a N/P ratio of 20 was investigated by DLS (Fig. 10). Naked DNA displayed a hydrodynamic diameter of $88 \pm 24 \mathrm{~nm}$. Upon complexation of DNA with $\mathrm{P}(\mathrm{AEAEMA})_{32}$, formation of polyplexes having a hydrodynamic diameter of $125 \pm 51 \mathrm{~nm}$ was observed. The high N/P ratio ensures that the polyplex particles possess a positive surface charge which results in the repulsive forces preventing the aggregation tendency between polyplex particles. When complexation was performed with $\mathrm{P}(\text { AEAEMA })_{13}-b-\mathrm{P}(\mathrm{ManAc})_{7}$, the polyplex particles displayed a much smaller hydrodynamic diameter $(38 \pm 10 \mathrm{~nm})$. In this case, the presence of the hydrophilic glycopolymer block might provide stability to polyplex particles in aqueous solution by preventing the association of a higher number of polymeric chains with DNA molecules, leading to the formation of particles with smaller hydrodynamic diameter. Additionally, as the gel electrophoresis results also indicated, it is possible that the shorter P(AEAEMA) block in the copolymer (with respect to the homopolymer used) can interact with the DNA fragment more efficiently, leading to a higher level of condensation of DNA chains. These results are in agreement with previous work of Ahmed and Narain, ${ }^{52}$ showing that the size of DNA polyplexes depends on the architecture of the polymer, and the length of the cationic chain. In this work, it was hypothesized that the block copolymers composed of cationic and carbohydrate blocks condense DNA efficiently in their core with a shell of the carbohydrate segment and hence yielding smaller particles as compared to statistical copolymers. Similarly, the same study showed that a low molecular weight cationic homopolymer formed smaller particles with plasmid DNA than higher molecular weight counterparts. 


\section{Conclusions}

The aim of this study was to synthesize and characterize a new, spermine-like, amine containing, well-defined polymer as a potential endosomal escaping agent. For this purpose, a new monomer, 2-((tert-butoxycarbonyl)(2-((tert-butoxycarbonyl)amino)ethyl)amino)ethylmethacrylate (BocAEAEMA), was synthesized and polymerized via RAFT polymerization. Welldefined BocAEAEMA polymers with controlled molecular weights and narrow molecular weight distributions were obtained. The polymers after deprotection, P(AEAEMA) displayed proton sponge capacity comparable with a widely used endosomal-disruptive polymer, PEI (25 kDa). More importantly, $\mathrm{P}$ (AEAEMA) did not show a cytotoxic effect on mouse fibroblast cells at concentrations where PEI was highly toxic. P(AEAEMA) was able to fully condense a $700 \mathrm{bp}$ DNA fragment at N/P ratios of 10 and above. Moreover, RAFT-synthesized P(AEAEMA) could be chain extended with a sugar monomer, ManAc, to yield $\mathrm{P}$ (AEAEMA)- $b$-P(ManAc) block copolymers. Although the presence of the ManAc block partially inhibited the interaction of $\mathrm{P}(\mathrm{AEAEMA})$ with DNA, the copolymer was able to form polyplexes with DNA at the N/P ratios tested.

Overall the results strongly encourage further investigations on the use of P(AEAEMA) as an endosomal-escaping agent. The endosomal escaping ability, intracellular distribution profile and transfection ability of P(AEAEMA) are currently being investigated in our laboratories.

\section{Acknowledgements}

The authors acknowledge the UK-Turkey Higher Education Knowledge Partnership Programme for funding student exchange, conference visits and some of research materials through TR/012012/KP25 grant, Bioengineering Research and Application Centre (Izmir Institute of Technology, Turkey) for providing cell culture research facilities, and Izmir Institute of Technology for research funding through BAP2011IYTE04.

\section{Notes and references}

1 G. Sahay, W. Querbes, C. Alabi, A. Eltoukhy, S. Sarkar, C. Zurenko, E. Karagiannis, K. Love, D. L. Chen, R. Zoncu, Y. Buganim, A. Schroeder, R. Langer and D. G. Anderson, Nat. Biotechnol., 2013, 31, 653.

2 H. Uchida, K. Miyata, M. Oba, T. Ishii, T. Suma, K. Itaka, N. Nishiyama and K. Kataoka, J. Am. Chem. Soc., 2011, 133, 15524.

3 V. Bagnacani, V. Franceschi, M. Bassi, M. Lomazzi, G. Donofrio, F. Sansone, A. Casnati and R. Ungaro, Nat. Commun., 2013, 4, 1721.

4 R. Iwai, R. Haruki, Y. Nemoto and Y. Nakayama, Bioconjugate Chem., 2013, 24, 159.

5 C. Wong-Baeza, I. Bustos, M. Serna, A. Tescucano, V. Alcantara-Farfan, M. Ibanez, C. Montanez, C. Wong and I. Baeza, Biochem. Biophys. Res. Commun., 2010, 396, 549.

6 A. Dehshahri, R. K. Oskuee, W. T. Shier, A. Hatefi and M. Ramezani, Biomaterials, 2009, 30, 4187.
7 J. K. GuyCaffey, V. Bodepudi, J. S. Bishop, K. Jayaraman and N. Chaudhary, J. Biol. Chem., 1995, 270, 31391.

8 Z. Du, M. Chen, Q. He, Y. Zhou and T. Jin, Int. J. Pharm., 2012, 434, 437.

9 K. Itaka, N. Kanayama, N. Nishiyama, W.-D. Jang, Y. Yamasaki, K. Nakamura, H. Kawaguchi and K. Kataoka, J. Am. Chem. Soc., 2004, 126, 13612.

10 S. M. Alex, M. R. Rekha and C. P. Sharma, Int. J. Pharm., 2011, 410, 125.

11 S.-H. Hong, J.-E. Kim, Y.-K. Kim, A. Minai-Tehrani, J.-Y. Shin, B. Kang, H.-J. Kim, C.-S. Cho, C. Chae, H.-L. Jiang and M.-H. Cho, Int. J. Nanomed., 2012, 7, 2293.

12 M. A. Maslov, T. O. Kabilova, I. A. Petukhov, N. G. Morozova, G. A. Serebrennikova, V. V. Vlassov and M. A. Zenkova, J. Controlled Release, 2012, 160, 182.

13 W. T. Godbey, K. K. Wu and A. G. Mikos, J. Biomed. Mater. Res., 1999, 45, 268.

14 W. T. Godbey, K. K. Wu and A. G. Mikos, J. Controlled Release, 1999, 60, 149.

15 O. Boussif, F. Lezoualc'h, M. A. Zanta, M. D. Mergny, D. Scherman, B. Demeneix and J. P. Behr, Proc. Natl. Acad. Sci. U. S. A., 1995, 92, 7297.

16 R. Deng, Y. Yue, F. Jin, Y. Chen, H.-F. Kung, M. C. M. Lin and C. Wu, J. Controlled Release, 2009, 140, 40.

17 W. Y. Seow, K. Liang, M. Kurisawa and C. A. E. Hauser, Biomacromolecules, 2013, 14, 2340.

18 H. L. Jiang, H. T. Lim, Y. K. Kim, R. Arote, J. Y. Shin, J. T. Kwon, J. E. Kim, J. H. Kim, D. Kim, C. Chae, J. W. Nah, Y. J. Choi, C. S. Cho and M. H. Cho, Eur. J. Pharm. Biopharm., 2011, 77, 36.

19 S. M. Alex, M. R. Rekha and C. P. Sharma, Int. J. Pharm., 2011, 410, 125.

20 A. H. Alidedeoglu, A. W. York, C. L. McCormick and S. E. Morgan, J. Polym. Sci., Part A: Polym. Chem., 2009, 47, 5405.

21 B. Yu and A. B. Lowe, J. Polym. Sci., Part A: Polym. Chem., 2009, 47, 1877.

22 N. J. Treat, D. Smith, C. Teng, J. D. Flores, B. A. Abel, A. W. York, F. Huang and C. L. McCormick, ACS Macro Lett., 2012, 1, 100.

23 L. C. Paslay, B. A. Abel, T. D. Brown, V. Koul, V. Choudhary, C. L. McCormick and S. E. Morgan, Biomacromolecules, 2012, 13, 2472.

24 C. Zhu, S. Jung, G. Si, R. Cheng, F. Meng, X. Zhu, T. G. Park and Z. Zhong, J. Polym. Sci., Part A: Polym. Chem., 2010, 48, 2869.

25 M. A. Nash, J. J. Lai, A. S. Hoffman, P. Yager and P. S. Stayton, Nano Lett., 2010, 10, 85.

26 B. B. Lundy, A. Convertine, M. Miteva and P. S. Stayton, Bioconjugate Chem., 2013, 24, 398.

27 C. Boyer, J. Teo, P. Phillips, R. B. Erlich, S. Sagnella, G. Sharbeen, T. Dwarte, H. T. T. Duong, D. Goldstein, T. P. Davis, M. Kavallaris and J. McCarroll, Mol. Pharm., 2013, 10, 2435.

28 J. T. Wilson, S. Keller, M. J. Manganiello, C. Cheng, C.-C. Lee, C. Opara, A. Convertine and P. S. Stayton, ACS Nano, 2013, 7, 3912. 
29 C. Cheng, A. J. Convertine, P. S. Stayton and J. D. Bryers, Biomaterials, 2012, 33, 6868.

30 S. Kirkland-York, Y. L. Zhang, A. E. Smith, A. W. York, F. Q. Huang and C. L. McCormick, Biomacromolecules, 2010, 11, 1052.

31 S. Sevimli, S. Sagnella, M. Kavallaris, V. Bulmus and T. P. Davis, Polym. Chem., 2012, 3, 2057.

32 A. Krieg, C. Weber, R. Hoogenboom, C. R. Becer and U. S. Schubert, ACS Macro Lett., 2012, 1, 776.

33 J. Y. Quek, P. J. Roth, R. A. Evans, T. P. Davis and A. B. Lowe, J. Polym. Sci., Part A: Polym. Chem., 2013, 51, 394.

34 G. Moad, E. Rizzardo and S. H. Thang, Aust. J. Chem., 2012, 65, 985 .

35 G. Moad, E. Rizzardo and S. H. Thang, Polym. Int., 2011, 60, 9.

36 M. Ahmed and R. Narain, Prog. Polym. Sci., 2013, 38, 767.

37 V. Bulmus, Polym. Chem., 1463, 2011, 2.

38 C. Boyer, M. H. Stenzel and T. P. Davis, J. Polym. Sci., Part A: Polym. Chem., 2011, 49, 551.

39 C. Boyer, V. Bulmus, T. P. Davis, V. Ladmiral, J. Liu and S. Perrier, Chem. Rev., 2009, 109, 5402.

40 A. Gregory and M. H. Stenzel, Prog. Polym. Sci., 2012, $37,38$.
41 C. Moura, R. F. Vitor, L. Maria, A. Paulo, I. C. Santos and I. Santos, Dalton Trans., 2006, 47, 5630.

42 R. S. Burke and S. H. Pun, Bioconjugate Chem., 2010, 21, 140. 43 L. Wong, S. Sevimli, H. M. Zareie, T. P. Davis and V. Bulmus, Macromolecules, 2010, 43, 5365.

44 Q. Zhang, J. Collins, A. Anastasaki, R. Wallis, D. A. Mitchell, C. R. Becer and D. M. Haddleton, Angew. Chem., Int. Ed., 2013, 52, 4435.

45 D. Pissuwan, C. Boyer, K. Gunasekaran, T. P. Davis and V. Bulmus, Biomacromolecules, 2010, 11, 412.

46 C. Boyer, A. Granville, T. P. Davis and V. Bulmus, Polym. Sci., Part A: Polym. Chem., 2009, 47, 3773.

47 C. Boyer, J. Q. Liu, V. Bulmus and T. P. Davis, Aust. J. Chem., 2009, 62, 830 .

48 C. Barner-Kowollik, M. L. Coote, T. P. Davis, L. Rado and P. Vana, Polym. Sci., Part A: Polym. Chem., 2003, 41, 2828.

49 G. Odian, Principles of Polymerization, Radical Chain Polymerization, John Wiley \& Sons, Inc, New Jersey, 2004.

50 D. Voet and J. G. Voet, Biochemistry, John Wiley \& Sons, Hoboken, NJ, 2011, p. 49.

51 J. Weyermann, D. Lochmann and A. Zimmer, Int. J. Pharm., 2005, 288, 369.

52 M. Ahmed and R. Narain, Biomaterials, 2011, 32, 5279. 